\title{
Effects of land use and climate change on ecosystem services in Central Asia's arid regions: A case study in Altay Prefecture, China
}

\author{
Qi Fu ${ }^{a}$, Bo Li ${ }^{\text {a,* }}$, Ying Hou ${ }^{b}, \mathrm{Xu} \mathrm{Bi}^{\text {a }}$, Xinshi Zhang ${ }^{\mathrm{a}, \mathrm{c}}$ \\ ${ }^{a}$ College of Resources Science \& Technology, Faculty of Geographical Science, Beijing Normal University, 100875 Beijing, China \\ b State Key Laboratory of Urban and Regional Ecology, Research Center for Eco-Environmental Sciences, Chinese Academy of Sciences, 100085 Beijing, China \\ c Institute of Botany, Chinese Academy of Sciences, 100093 Beijing, China
}

\section{H I G H L I G H T S}

- The study area is representative of the mountain-oasis-desert system.

- Four ecosystem services are assessed based on biophysical models.

- Different land use and climate change conditions are established.

- The influences of land use and climate change are demonstrated.

- Some targeted ecosystem management strategies are proposed.

\section{G R A P H I C A L A B S T R A C T}

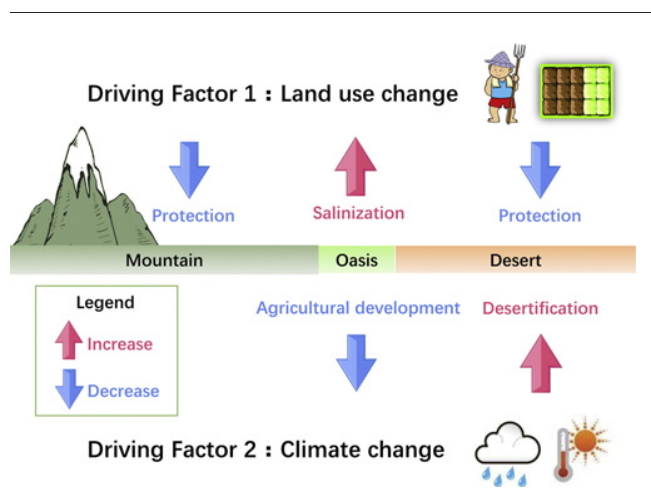

\begin{abstract}
A B S T R A C T
The sustainable use of ecosystem services (ES) can contribute to enhancing human well-being. Understanding the effects of land use and climate change on ES can provide scientific and targeted guidance for the sustainable use of ES. The objective of this study was to reveal the way in which land use and climate change influence the spatial and temporal variations of ES in the mountain-oasis-desert system (MODS). In this study, we assessed water yield, soil conservation, crop production, and sand fixation in 1990, 2000, and 2010 in Altay Prefecture, which is representative of the MODS, based on widely used biophysical models. Moreover, we analyzed the effects of different land use and climate change conditions on ES. The results show that the area of forest and bare land decreased in Altay Prefecture. In contrast, the area of grassland with low coverage and cropland increased. The climate of this area presented an overall warming-wetting trend, with warming-drying and cooling-wetting phenomena in some areas. Soil conservation in the mountain zone, water yield in the oasis zone, and sand fixation in the desert zone all decreased under the influence of land use change alone. The warming-drying trend led to decreased water yield in the oasis zone and increased wind erosion in the desert zone. Based on the results, we recommend that local governments achieve sustainable use of ES by planting grasslands with high coverage in the oasis zone, increasing investment in agricultural science and technology, and establishing protected areas in the mountain and desert zones. The methodology in our study can also be applied to other regions with a MODS structure.
\end{abstract}

(c) 2017 Elsevier B.V. All rights reserved.

\footnotetext{
* Corresponding author.

E-mail address: libo@bnu.edu.cn (B. Li).
} 


\section{Introduction}

Ecosystem services (ES) refer to the direct and indirect benefits that people obtain from ecosystems, including products and services (Costanza et al., 1997). The scientific issues related to ES have received attention from many scholars in the fields of geography, ecology, and economics over the past 20 years (Bennett et al., 2005; Burkhard et al., 2014; Daily, 1997; Kremen, 2005; Perrings et al., 2010). With global population growth, social development, and technological progress, humans are constantly changing the natural world. This simultaneously changes the material cycling and energy flow of ecosystems, thus affecting ES and human well-being (Vitousek et al., 1997). The Millennium Ecosystem Assessment (MEA) evaluated the changes in 24 ES worldwide under the influence of multiple driving forces and the results showed that 15 ES are currently declining (over $60 \%$ of the total ES). This trend will be aggravated by future global warming (MEA, 2005). In the arid regions of Xinjiang, China, human living conditions and social development are highly dependent on natural resources. However, in recent years, people have overexploited the productivity of the grasslands while neglecting their ecological function. Overgrazing and land reclamation have led to the decline and degradation of ES in many areas (Wu et al., 2007). Therefore, it is urgent that the mechanisms driving changes in ES be studied.

Land use/land cover and climate change are considered the two main driving factors of ES change (Bateman et al., 2013; Schröter et al., 2005). Land use/land cover change alters the supply of ES by influencing ecosystem patterns and processes (Fu and Zhang, 2014). Climate change affects ES directly or indirectly by changing hydrological processes, $\mathrm{CO}_{2}$ concentration, etc. (Nelson et al., 2013). Recent research has shown that an increase in agricultural areas, urbanization, grazing, and other factors have led to the reduction in carbon storage, water quality, and biodiversity, resulting in a significant decline in ES (Le Maitre et al., 2007; Li et al., 2013; Polasky et al., 2011). In the context of climate change, many regions are experiencing warming and drying trends, which has increased the possibility of water shortages, natural disasters, and desertification and has placed considerable pressure on the sustainable use of ES (Schröter et al., 2005). To mitigate these negative impacts, it is essential to develop effective ecosystem management and land use strategies.

When decision-makers and scientists manage ecosystems, they must understand the spatial features, change dynamics, and influencing factors of ES. To date, researchers have conducted multiple studies related to ES, some of which have investigated changes in the values of ES and the relationships with influencing factors (Chuai et al., 2016; Estoque and Murayama, 2012; Mendoza-González et al., 2012; Wang et al., 2014). Others have used biophysical models to simulate changes in the physical quantity of the ES and their relationship with influencing factors (Jiang et al., 2016; Lorencová et al., 2013; Nelson et al., 2010; Su and $\mathrm{Fu}, 2013)$. However, in earlier research, correlation analysis was typically used to analyze the effects of land use/land cover and climate change on ES. This can only qualitatively determine the changes in factors that are most influential. Only a few studies have explored in depth the related ecological processes and ecological significance of these effects and proposed targeted countermeasures. Moreover, researchers have generally focused on urban ecosystems and have paid less attention to ES in arid regions.

An alternating distribution of mountains and basins is the basic feature of the natural geography of the arid regions of Central Asia. This combination of terrestrial ecosystems has been termed a mountainoasis-desert system (MODS) by Zhang (2001). It is a composite system consisting of a vertical mountain vegetation belt and a concentric annular (geologic landform) vegetation belt in a desert basin (Fig. 1). The three subsystems, mountain, oasis, and desert, are not isolated from each other but are linked through the flow of energy, material, life, values, and culture. This classic model has been widely applied to studies of the arid regions of northwest China (Dong et al., 2006; Wu and Zhang, 2000; Zhang, 2011), but there have been few comprehensive studies linking the MODS and ES.

To narrow the research gaps, we assessed ES in Altay Prefecture, which is representative of the MODS, and we investigated the effects of land use and climate change on ES during 1990-2010. The objective of this study was to reveal the way in which land use and climate change influence spatial and temporal variations of ES in Altay Prefecture. Given this challenge, three questions were addressed: (1) What characterizes the process of change in ES over the past 20 years in the Altay Prefecture? (2) How do land use and climate change influence ES and where do the influences occur in the Altay Prefecture? (3) How can ecosystems with a MODS structure be managed to promote the sustainable use of ES? We provide a methodology to quantify the influences of land use and climate change on ES and to identify the location of the influences. This study has the potential to provide scientific support for the sustainable use of ES in Altay Prefecture, and the methodology can be applied to other regions with a MODS structure.

\section{Materials and methods}

\subsection{Study area}

Altay Prefecture $\left(44^{\circ} 59^{\prime} 35^{\prime \prime} \sim 49^{\circ} 10^{\prime} 45^{\prime \prime} \mathrm{N}, 85^{\circ} 31^{\prime} 57^{\prime \prime} \sim 91^{\circ} 01^{\prime} 15^{\prime \prime} \mathrm{E}\right)$ is located in the northernmost part of the Xinjiang Uygur Autonomous Region, China, which borders Kazakhstan, Russia, and Mongolia (Fig. 2). The total area is approximately $118,000 \mathrm{~km}^{2}$, and the total population is approximately 675,900 (2015). The altitude in Altay Prefecture gradually declines from the Altai Mountains in the north to the Junggar Desert in the south and the terrain is characterized by a steppe-like topography. The region has a typical temperate continental climate with a mean annual precipitation ranging from $139.3 \mathrm{~mm}$ to $268.4 \mathrm{~mm}$ and a mean annual temperature ranging from $0.7^{\circ} \mathrm{C}$ to $4.9^{\circ} \mathrm{C}$ (Gulzat and Zhao, 2011). The water resources in this region are unevenly distributed both spatially and temporally, and there exists considerable interannual variability in the amount of runoff. Spatially,

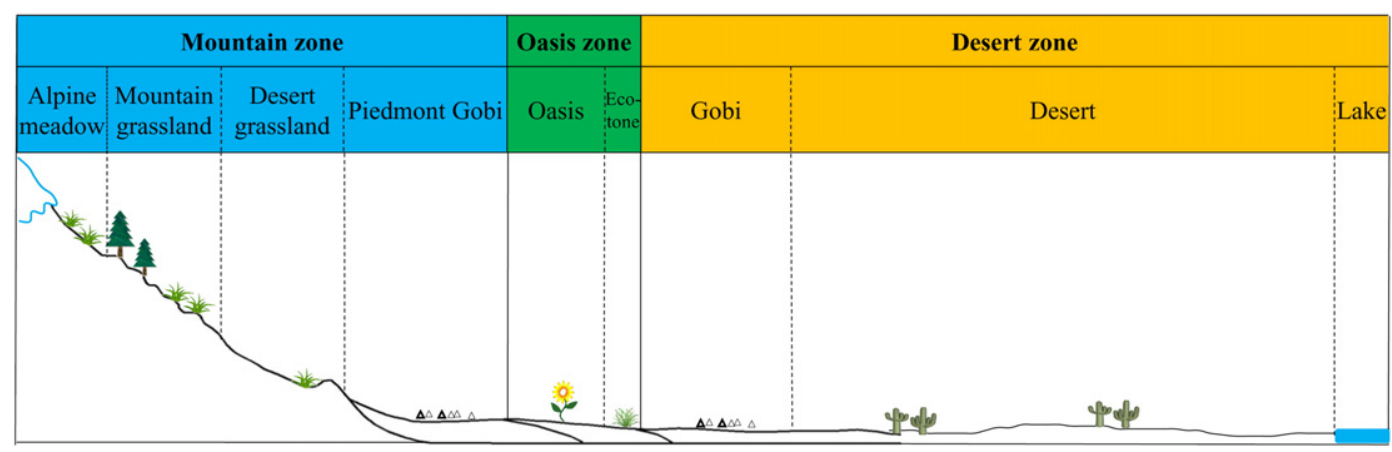

Fig. 1. Sectional diagram of the MODS landscape. 

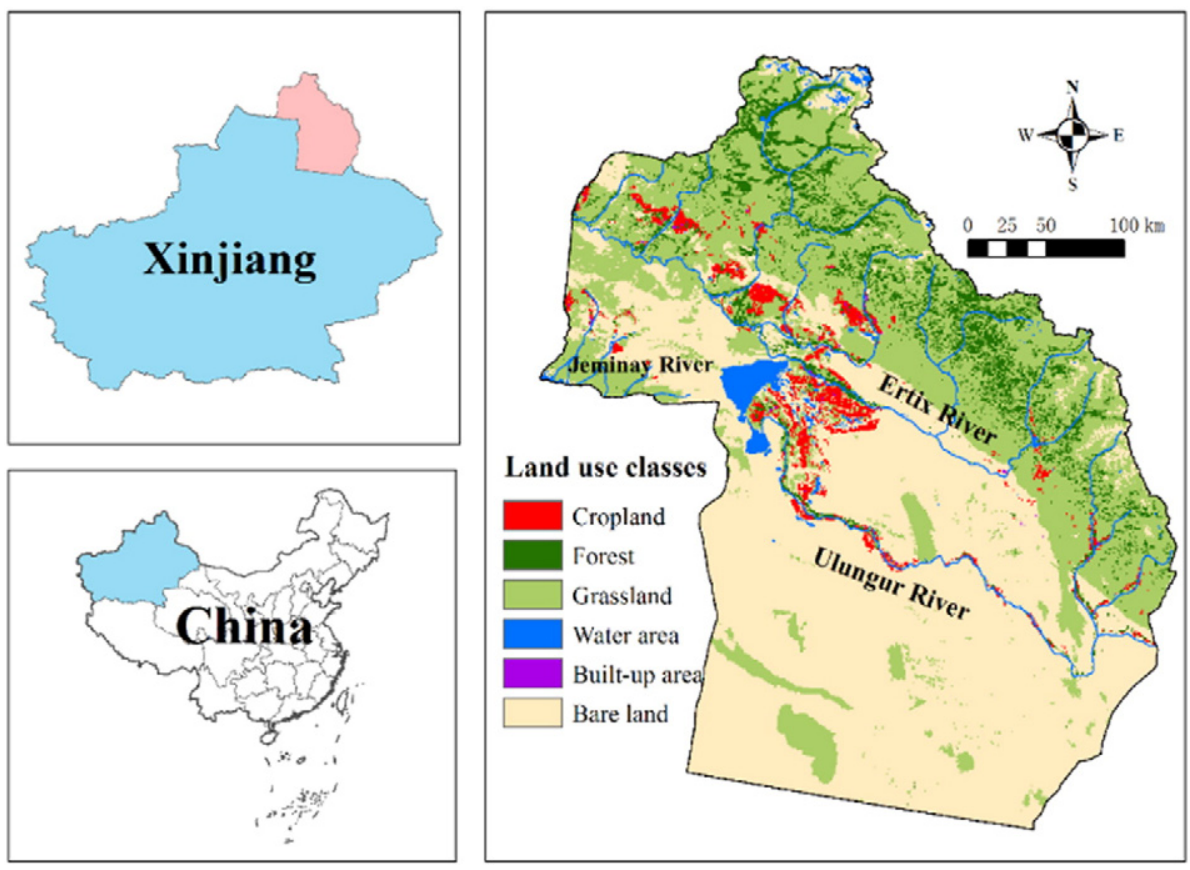

Fig. 2. Location of Altay Prefecture.

more water resources exist in the west and north than in the east and south.

Grassland degradation is a serious issue in the Altay Prefecture due to the interaction between natural and anthropogenic factors, such as drought, land reclamation, and overgrazing. The total area of usable grassland is $72,000 \mathrm{~km}^{2}$, while degraded grassland accounts for $64 \%$ of the area. Although the government has implemented a policy of stable settlements for the herdsmen, the livestock in the settlement areas continue to rely on natural grassland due to delays in the construction of water conservancy projects, a lack of land for forage grass, etc. The livestock in farming areas graze in pastures occupying a large portion of the grassland, and they compete with livestock reared in the pastoral areas. This situation has become the primary reason for overgrazing.
Overgrazing and drought have led to large-scale grassland degradation, especially in the spring and autumn pastures in the mountains, which are subject to grazing pressure twice a year. At the same time, farmers have made large efforts to reclaim shrublands, grasslands, and unused land to improve their livelihoods, resulting in increasingly severe problems, such as secondary salinization and land desertification.

\subsection{Division of landscape zones in the MODS}

During the field survey (Fig. 3a), we observed an obvious vertical zonal distribution of landscape types in Altay Prefecture. Therefore, to further analyze the changes in the ES of the MODS, we obtained a digital elevation model (DEM), a vegetation map, and a physiognomy map as
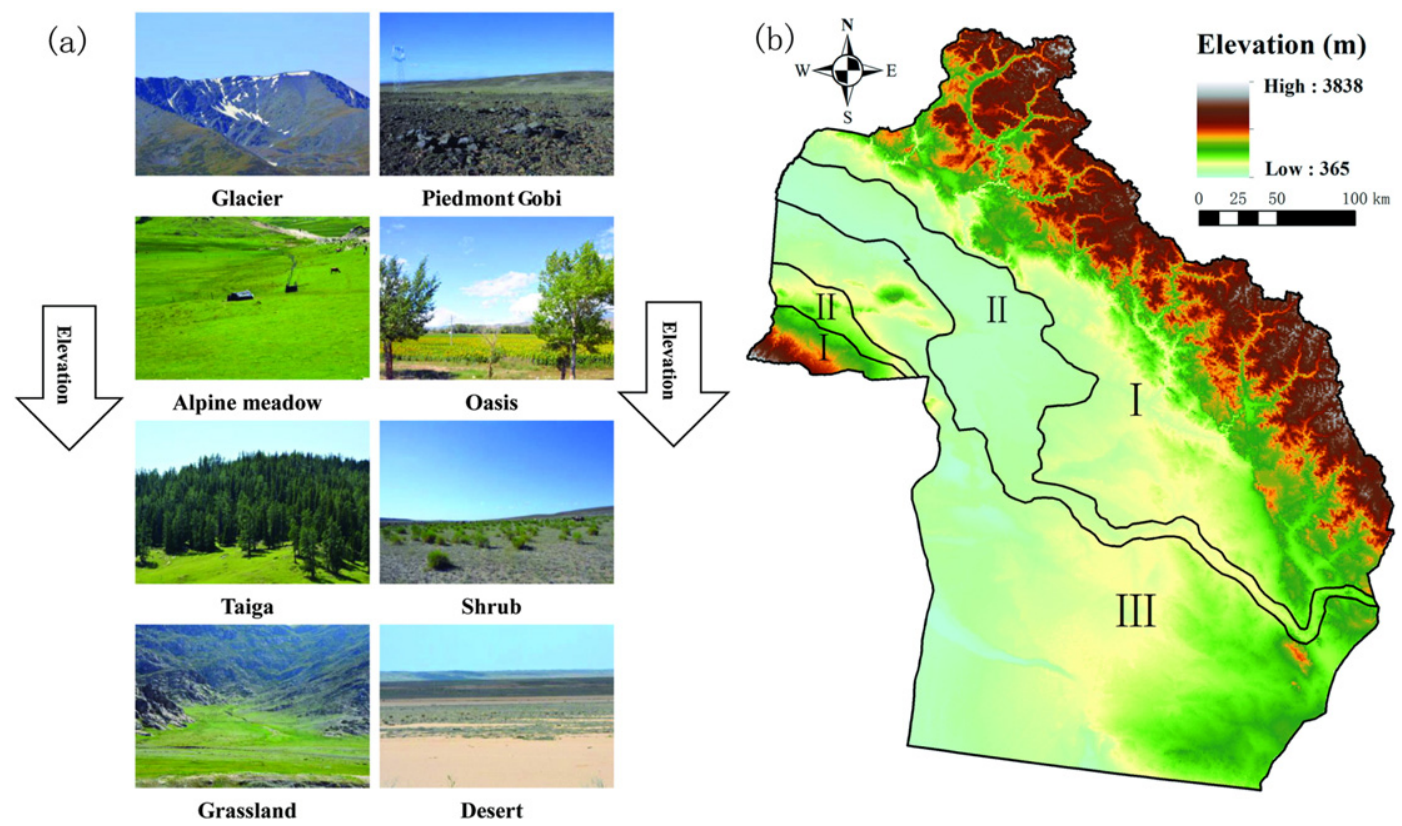

Fig. 3. (a) Survey photos of the different landscapes; (b) drawing showing the different MODS landscape zones (I-mountain zone, II-oasis zone, and III-desert zone) 
references. Using these, we divided the study area into three zones according to the differences in the physical geography: the mountain zone (including the piedmont Gobi), the oasis zone (including the oasis-desert ecotone), and the desert zone (Fig. 3b). Distinguishing among MODS landscape zones can help to propose more targeted ecosystem management strategies.

\subsection{Ecosystem services assessment}

Human activities in Altay Prefecture are mainly concentrated in long and narrow oases, and the desert and mountains provide critical resources that support the development of these oases. At the same time, natural disasters originating in the mountains and desert, such as debris flows and sandstorms, often threaten the oases. Therefore, after considering the local conditions, the feasibility of the assessment method, and the availability of data, we chose water yield, soil conservation, crop production, and sand fixation as the objects of this study.

In this study, water yield was assessed according to the equations of InVEST, a model that was jointly developed by Stanford University, The Nature Conservancy (TNC), and the World Wide Fund for Nature (WWF) (Tallis and Polasky, 2009). Soil conservation was assessed with the Universal Soil Loss Equation (USLE), which was developed by the United States Department of Agriculture. We assessed crop production according to the equations of the SAORES model, a spatially explicit assessment and optimization tool for regional ES. We evaluated sand fixation using the Revised Wind Erosion Equation (RWEQ). To improve the accuracy of the soil conservation and sand fixation assessments, we converted the soil particle diameter and corrected the soil erodibility factor, wind speed factor, and other parameters.

\subsubsection{Water yield}

Based on the water balance principle and the Budyko curve, the InVEST development team designed the Water Yield model. This model can calculate the water yield of each grid based on climate data, land use data, and other sources. In recent years, the InVEST model has been widely used in studies of water supply services at drainage basin or regional scales (Chen et al., 2013; Hou et al., 2016). The calculations are as follows:

$Y_{j x}=\left(1-A E T_{x j} / P_{x}\right) \times P_{x}$

$A E T_{x j} / P_{x}=\left(1+\omega_{x} R_{x j}\right) /\left(1+\omega_{x} R_{x j}+1 / R_{x j}\right)$

$R_{x j}=K_{x j} \cdot E T_{0} / P_{x}$

$\omega_{x}=Z \times A W C_{x} / P_{x}$

$A W C=\operatorname{Min}($ Soil Depth, Root Depth $) \times P A W C$

where $Y_{j x}$ is the annual water yield $\left(\mathrm{m}^{3}\right)$ of land use type $j$ in grid $x$; $A E T_{x j}$ is the average annual actual evapotranspiration of grid $x$ $(\mathrm{mm})$; and $P_{x}$ is the average annual precipitation $(\mathrm{mm})$ of grid $x$. $A E T_{x j} / P_{x}$ approximates the Budyko curve developed by Zhang et al. (2001). $R_{x j}$ is the Budyko aridity index (dimensionless) of grid $x ; K_{x j}$ is the coefficient of vegetation evapotranspiration; $E T_{0}$ is the potential evapotranspiration $(\mathrm{mm}) ; \omega_{x}$ is a dimensionless ratio characterizing the natural climate and soil properties; $A W C_{x}$ is the volumetric $(\mathrm{mm})$ plant available water content; and $P A W C$ is the plant available water capacity (0-1). $Z$ is the Zhang coefficient (Zhang et al., 2001), which ranges from 1 to 10 and needs to be calibrated with monitoring data from the local hydrometric stations. When the Zhang coefficient is equal to 9, the deviation for simulated and observed water yield is the smallest (7.8\%).

The input data included average annual precipitation, annual potential evapotranspiration, root depth, soil depth, plant available water content, etc. The average annual precipitation was obtained by interpolation and the root depth data was based on the study of Canadell et al. (1996). The soil depth data came from the Second National Soil Survey of China; $K$ was derived from the InVEST user's guide (Sharp et al.,
2016); and PAWC was calculated based on the soil texture according to Zhou et al. (2005). The $E T_{0}$ was calculated based on the 'modified Hargreaves' equation.

\subsubsection{Soil conservation}

Previous studies have shown that the USLE can effectively simulate the ecosystem function of erosion control (Fu et al., 2011; Lü et al., 2012). We used the USLE model to simulate the potential amount of soil erosion and the actual amount soil erosion; the difference between the two is the amount of soil conservation. In particular, the type of soil erosion in this study is water erosion and the calculation is as follows:

$$
\begin{aligned}
& A_{c}=A_{r}-A \\
& A=R \times K \times L \times S \times C \times P \\
& A_{r}=R \times K \times L \times S
\end{aligned}
$$

where $A_{c}$ is the amount of soil conservation $\left(\mathrm{t} \cdot \mathrm{hm}^{-2} \cdot \mathrm{a}^{-1}\right) ; A$ is the amount of actual soil erosion $\left(\mathrm{t} \cdot \mathrm{hm}^{-2} \cdot \mathrm{a}^{-1}\right) ; A_{r}$ is the amount of potential soil erosion $\left(\mathrm{t} \cdot \mathrm{hm}^{-2} \cdot \mathrm{a}^{-1}\right) ; R$ is the rainfall erosivity factor $\left(\mathrm{MJ} \cdot \mathrm{mm} \cdot \mathrm{hm}^{-2} \cdot \mathrm{h}^{-1}\right) ; K$ is the soil erodibility factor $\left(\mathrm{t} \cdot \mathrm{hm}^{2} \cdot\right.$ $\left.\mathrm{h} \cdot \mathrm{hm}^{-2} \cdot \mathrm{MJ}^{-1} \cdot \mathrm{mm}^{-1}\right) ; L$ is the slope length factor (dimensionless); $S$ is the slope angle factor (dimensionless); and $C$ and $P$ represent the current vegetation cover and erosion control factors (dimensionless), respectively.

The rainfall erosivity factor $R$ was calculated using the empirical equations for arid and semiarid lands proposed by Wischmeier and Smith (1965). The soil erodibility factor $K$ was determined using the erosion-productivity impact calculator (EPIC) model (Sharpley and Williams, 1990) and was corrected according to the study of Zhang et al. (2007). The slope length factor was calculated according to Liu et al. (2000). Two methods were used to calculate the slope angle factor. The formula of McCool et al. (1987) was used for gentle slopes and the formula of Liu et al. (1994) was used for steep slopes. The factors $C$ and $P$ were calculated according to Cai et al. (2000).

\subsubsection{Crop production}

Researchers have performed many simulations of crop production and the potential attenuation is the most commonly used method. It incorporates corrected and accumulated potential photosynthetic productivity, potential light and temperature productivity, potential climate productivity, and potential land productivity in a stepwise manner. In recent years, some scholars have simplified the model and superimposed a cropland quality factor, which is based on potential climatic productivity to assess crop production (Zheng et al., 2014). In this study, crop production was assessed according to the equations of the SAORES model proposed by $\mathrm{Hu}$ et al. (2015) as follows:

$C P=N P P \times I_{z r d}$

where $C P$ represents crop production; NPP is the net primary productivity; and $I_{z r d}$ is the land-use level index, which is determined by the farm land grading regulations in China. We used the NPP calculation model proposed by Zhou and Zhang (1996), which is more suitable for arid regions when compared with the models of Miami, Thornthwaite, etc.

\subsubsection{Sand fixation}

Wind erosion is the root cause of desertification in arid and semiarid regions. It results in declining living standards for local farmers and herdsmen and even threatens human life and property. Wind erosion is primarily related to local climatic conditions, the natural underlying surface conditions, and human activities. The RWEQ model is used around the world, and it comprehensively considers the effects of wind speed, precipitation, temperature, soil texture, topography, and vegetation cover on wind erosion (Van Pelt et al., 2004). We assessed 
Table 1

Condition settings for analyzing the impacts of land use and climate change on ES.

\begin{tabular}{|c|c|c|c|c|}
\hline & Condition & 1990 & 2000 & 2010 \\
\hline \multirow[t]{2}{*}{ Land use and climate change } & Condition 1 & Climate 1990 & Climate 2000 & Climate 2010 \\
\hline & & Land use 1990 & Land use 2000 & Land use 2010 \\
\hline \multirow[t]{2}{*}{ Land use change } & Condition 2 & Climate1990 & & \\
\hline & & Land use 1990 & Land use 2000 & Land use 2010 \\
\hline Climate change & Condition 3 & $\begin{array}{l}\text { Climate } 1990 \\
\text { Land use } 1990\end{array}$ & Climate 2000 & Climate 2010 \\
\hline
\end{tabular}

the sand fixation in the Altay Prefecture based on the RWEQ model as follows:

$\Delta Q=Q_{0}-Q_{v}$

$Q_{(x)}=\left(2 \cdot Z / S^{2}\right) \cdot Q_{\max } \cdot e^{-(x / S)^{2}}$

$Q_{\max }=109.8 \cdot\left(W F \times E F \times S C F \times K^{\prime} \times C\right)$

$S=105.71 \cdot\left(W F \times E F \times S C F \times K^{\prime} \times C\right)^{-0.3711}$

where $\Delta Q$ is the amount of sand fixation $\left(\mathrm{t} \cdot \mathrm{km} \cdot \mathrm{a}^{-1}\right) ; Q_{0}$ is the amount of potential sand erosion without vegetation cover $\left(\mathrm{t} \cdot \mathrm{km}^{-2} \cdot \mathrm{a}^{-1}\right) ; Q_{v}$ is the amount of actual sand erosion with vegetation cover and management $\left(\mathrm{t} \cdot \mathrm{km}^{-2} \cdot \mathrm{a}^{-1}\right) ; Q_{(x)}$ is the amount of sand transported by the wind at a point $x$ downwind; $Q_{\max }$ is the maximum amount of sand that can be transported downwind; and $S$ is the critical field length. $W F$ is the weather factor; $E F$ is the soil erodibility factor; SCF is the soil crust factor; $K^{\prime}$ is the soil roughness factor; and $C$ is the vegetation cover factor.

The $W F, E F, S C F, K^{\prime}$, and $C$ factors were calculated as described by Jiang et al. (2016). In particular, the instruction manual for the RWEQ model specifies that the wind speed input parameter should be the average of wind speed data collected every 1 or 2 min (Fryrear et al., 1998), which is difficult to obtain. In this study, the average daily wind speed was used to estimate the amount of wind erosion, and the study by Guo (2012) on converting the wind factor between different wind speeds was taken as a reference.

\subsection{Land use and climate change conditions}

It is very difficult to completely separate the effects of land use and climate change on ES as the climate influences the biophysical characteristics of land resources (Zhang et al., 2014). However, an ecological model with different condition settings can offer an efficient way to explore the mechanism of ES changes (Geng et al., 2014; Nemani et al., 2003; Zhang et al., 2014). In this study, three conditions were used to analyze the effects of land use and climate change on ES from 1990 to 2010: Condition 1 for the combined and interactive effects of land use and climate change, Condition 2 for land use change only, and Condition 3 for climate change only (Table 1 ). Condition 1 reflected the actual change in ES during 1990-2010, which can be used as a control in the investigation of the effects of land use and climate change on ES. Condition 2 only allowed land use to change from 1990 to 2010 while the climatic factors in 1990 were held constant for the study period. This condition was used to analyze the effects of land use change on
ES. To examine the effects of climate change on ES, Condition 3 was used, in which land use was held constant from 1990 on while climatic factors were allowed to change from 1990 to 2010.

\subsection{Data preparation}

In this study, ArcGIS 9.3 was used as the GIS software platform. All vector and grid data were converted to the same projection coordinate system (Krasovsky_1940_Transverse_Mercator), and the grid data were resampled to a spatial resolution of $1 \mathrm{~km} \times 1 \mathrm{~km}$.

\subsubsection{Land use and climate data}

Land use data were provided by the Data Center for Resources and Environmental Sciences at the Chinese Academy of Sciences (RESDC) (http://www.resdc.cn/) and were based on Landsat TM/ETM + remote sensing images from multiple dates. The data were converted to a grid format at a spatial resolution of $1 \mathrm{~km} \times 1 \mathrm{~km}$. The climate data were obtained from a dataset of monthly values from the China Meteorological Data Sharing Service System (http://cdc.cma.gov.cn/), which included eight parameters, such as temperature, precipitation, sunshine duration, etc. The dataset was in ASCII format. To overcome the effects of extreme values in a single year while identifying meteorological data corresponding to the land use data for 1990, 2000, and 2010, we averaged the values of the meteorological data for three periods, 1985-1994, 1995-2004, and 2005-2014, for the interpolation. To improve the accuracy of the interpolation results, we referred to the method of Jing et al. (2013), in which latitude and longitude coordinates and topography elements were added to the climate data interpolation algorithm.

\subsubsection{Additional data preparation}

Data related to soil texture, depth, type, and other soil physical and chemical properties (including the proportions of sand, silt, and clay and the reference soil depth) were obtained from the Environmental and Ecological Science Data Centre for West China (http://westdc. westgis.ac.cn/). The data were in grid format with a spatial resolution of $1 \mathrm{~km} \times 1 \mathrm{~km}$, and the soil classification system developed by the Food and Agriculture Organization (FAO) was used (FAO-90). The DEM and normalized difference vegetation index (NDVI) data were obtained from the Geospatial Data Cloud of the Chinese Academy of Sciences (http://www.gscloud.cn/); the data were in grid format at a spatial resolution of $30 \mathrm{~m} \times 30 \mathrm{~m}$ and $250 \mathrm{~m} \times 250 \mathrm{~m}$, respectively. The basic geographic information data in the Altay Prefecture were

Table 2

Transition matrix of land use change during 1990-2010 $\left(\mathrm{km}^{2}\right)$.

\begin{tabular}{|c|c|c|c|c|c|c|c|}
\hline $\begin{array}{l}2010 \\
1990\end{array}$ & Forest & Grassland & Water & Built-up area & Bare land & Cropland & Transfer-out area \\
\hline Forest & 4600 & 4492 & 43 & 11 & 371 & 212 & 5129 \\
\hline Grassland & 3492 & 31,661 & 147 & 18 & 2939 & 749 & 7375 \\
\hline Water & 41 & 107 & 1341 & 2 & 208 & 13 & 371 \\
\hline Built-up area & 13 & 17 & 0 & 21 & 7 & 26 & 63 \\
\hline Bare land & 201 & 4212 & 326 & 12 & 58,468 & 959 & 5710 \\
\hline Cropland & 169 & 570 & 20 & 57 & 319 & 1496 & 1135 \\
\hline Transfer-in area & 3916 & 9398 & 536 & 100 & 3844 & 1959 & - \\
\hline
\end{tabular}



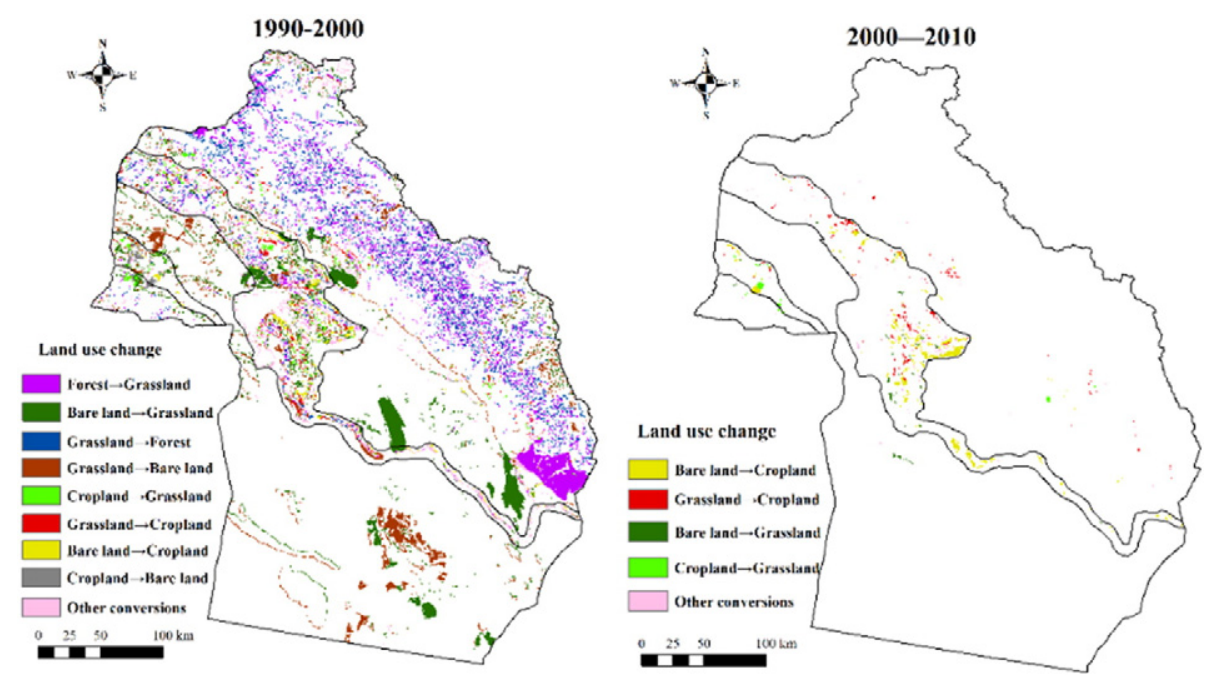

Fig. 4. Spatial distribution of land use change during 1990-2010.

provided by the Xinjiang and Central Asia Data Center (http://midasia. data.ac.cn/); these data were in vector format.

\section{Results}

\subsection{Land use and climate change}

\subsubsection{Land use change}

From 1990 to 2010, cropland, forest, grassland, and bare land were interconverted most frequently, while water and built-up areas only changed slightly (Table 2). The area of cropland showed an increasing trend $\left(822 \mathrm{~km}^{2}\right)$, mainly due to the conversion of grassland and bare land. The amount of bare land showed a decreasing trend $\left(1870 \mathrm{~km}^{2}\right)$, mainly due to its conversion to grassland and cropland. The grassland area tended to increase $\left(2062 \mathrm{~km}^{2}\right)$, mainly through the conversion of forest and bare land. It was noteworthy that, although the total amount of grassland increased, the type that expanded was mainly grassland with low coverage, while the amount of grassland with high coverage and middle coverage decreased. The area of forest decreased, with $4492 \mathrm{~km}^{2}$ converted to grassland. The built-up area and the water area fluctuated little.

As seen from the spatial distribution of land use change (Fig. 4), the oasis zone represented the area with the most frequent land use conversion. During 1990-2000, the conversion of forest to grassland mainly occurred in the mountain zone; the conversion of bare land to grassland mainly occurred in the oasis zone, the desert zone, and the piedmont Gobi; and the conversion of grassland to cropland and of bare land to cropland mainly occurred in the oasis zone. During 2000-2010, the land use change was primarily characterized by the interconversion between cropland and other types of land, and this change mainly occurred in the oasis zone. Comparing the two periods of 1990-2000 and 2000-2010, the change in land use was more intense in the first ten years than in the last ten years, especially for forest and grassland, which mostly changed in the first ten years. In the last ten years, the primary land use change was the expansion of cropland and the reduction of bare land. During this time, humans switched to exploiting desert resources, in contrast to the earlier exploitation of mountain resources.

\subsubsection{Climate change}

This study mainly characterized changes in precipitation, temperature, and radiation, which account for a relatively high proportion of the climate factors influencing ES. To overcome the effects of extreme meteorological data values in a single year, we selected data from 1985 to 2014 (Section 2.5.1). By calculating and analyzing the linear trends in climate change during 1985-2014, we found that the mean annual precipitation and mean annual temperature have increased at the rates of $1.4015 \mathrm{~mm} \cdot \mathrm{a}^{-1}$ and $0.0375{ }^{\circ} \mathrm{C} \cdot \mathrm{a}^{-1}$, while no obvious trend was observed for the mean annual radiation (Fig. 5). Overall, the climate in the study area showed a warming and wetting trend.

The spatial heterogeneity in climate change is worth noting, and it may have affected the spatial distribution and change in ES. Since a changing trend in the mean annual radiation was not obvious, precipitation and temperature are assumed the main factors driving spatial variations in climate change. Climate change over the past 20 years was calculated using spatial analysis tools in ArcGIS. The precipitation and temperature data were overlaid to determine the trend in the
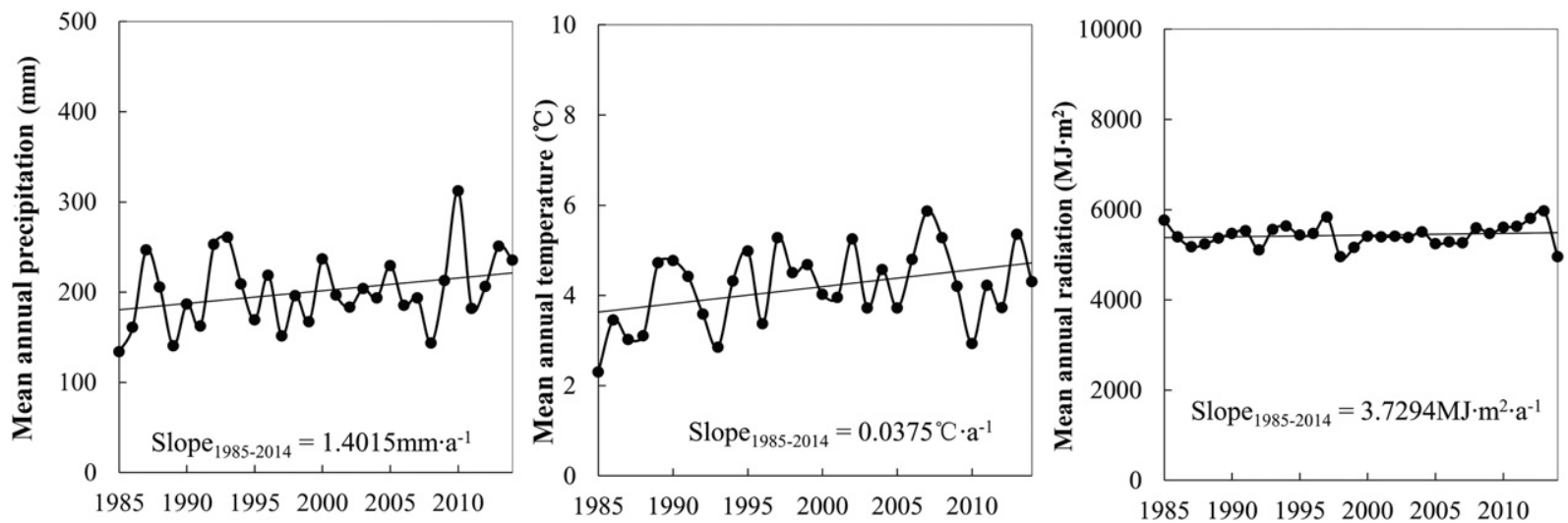

Fig. 5. Temporal variation in the mean annual precipitation, mean annual temperature, and mean annual radiation in Altay Prefecture during $1985-2014$. 

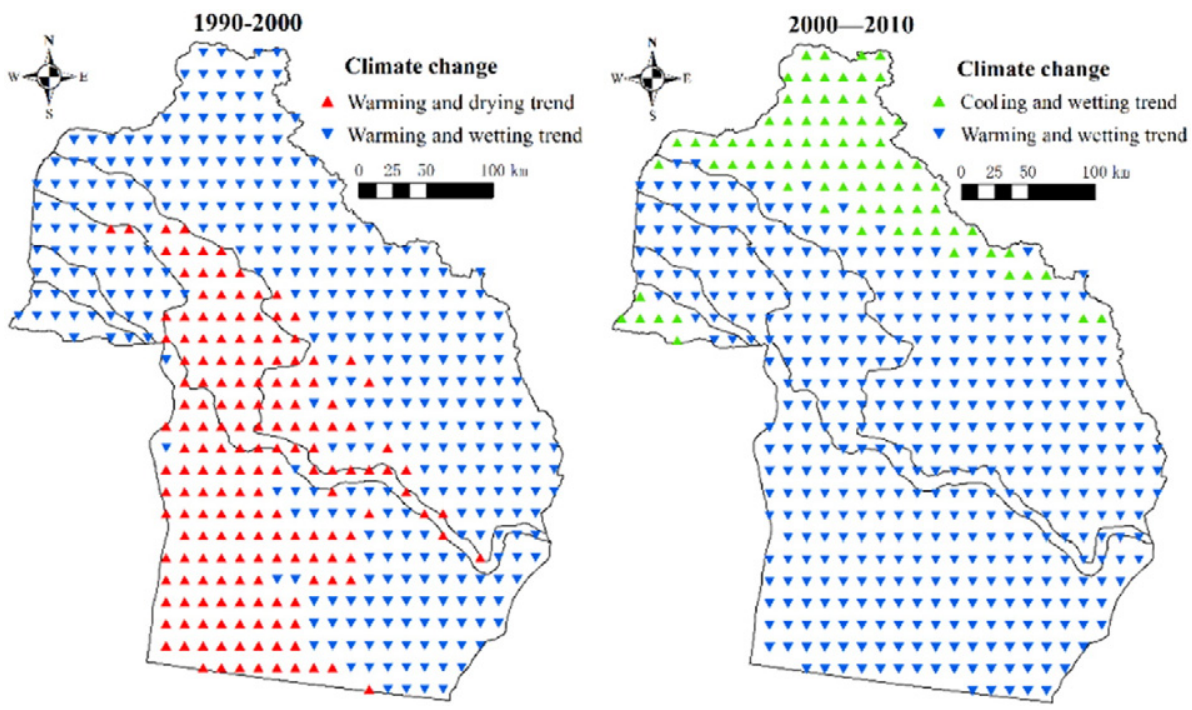

Fig. 6. Spatial distribution of climate change in Altay Prefecture during 1990-2010.

spatial distribution of the climatic factors (Fig. 6). During 1990-2000, the entire study area experienced a warming trend; specifically, a warming and drying trend was observed in most areas of the oasis zone and the western parts of the desert zones due to the decrease in precipitation. A warming and wetting trend was seen in the mountain zone and other areas. During 2000-2010, the drying trend was relieved and changed to a wetting trend due to the continuously increasing precipitation, leading to a warming and wetting trend in the oasis zone and western part of the desert zone. However, temperature decreases in the northern part of the mountain zone resulted in a cooling and wetting trend in this region.

\subsection{Changes in ecosystem services under different land use and climate change conditions}

\subsubsection{Condition 1: combination of land use and climate change}

Under the interactive influence of land use and climate change, the actual changes in ES over the past 20 years were as follows: (1) Water

(a) water yield

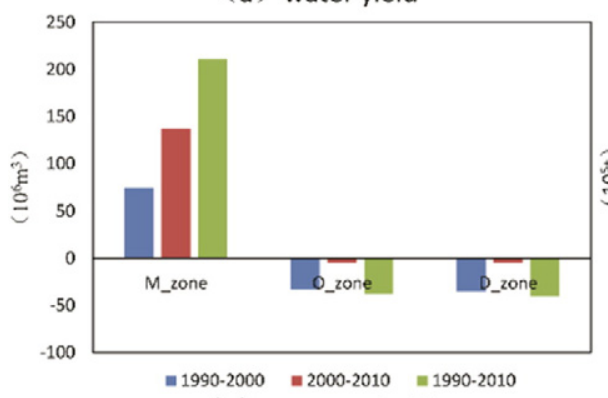

(c) crop production

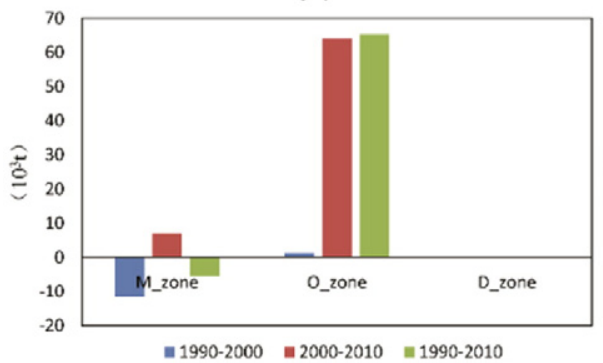

Yield. As seen from the statistical analyses, the water yield showed an overall increasing trend from 1990 to 2010, with a 2.03\% increase from $6.39 \times 10^{9} \mathrm{~m}^{3}$ in 1990 to $6.52 \times 10^{9} \mathrm{~m}^{3}$ in 2010 . However, the overall increase does not mean that water use became more efficient. Over the past 20 years, water yield continuously declined in the oasis and desert zones, especially in the first 10 years, when the decline was large (Fig. 7a). The area of decline was mainly in the oasis zone and the junction of the mountain zone with the oasis zone (Fig. 8a). (2) Soil Conservation. The amount of soil conservation in the study area increased overall, with an increase of $10.43 \%$ from $1.15 \times 10^{8}$ t in 1990 to $1.27 \times 10^{8} \mathrm{t}$ in 2010 . As seen in Fig. $7 \mathrm{~b}$, soil conservation increased significantly in the mountain zone and the increase was higher in the first 10 years than in the last 10 years. Despite the overall increase, the spatial distribution of soil conservation exhibited a decrease in the eastern mountain zone during 1990-2000 (Fig. 8b). (3) Crop Production. Crop production initially showed a declining trend followed by an increasing trend. From 1990 to 2000 , crop production decreased from $2.38 \times 10^{5} \mathrm{t}$ to $2.28 \times 10^{5}$ t, a $4.20 \%$ reduction. From 2000 to 2010 , crop production

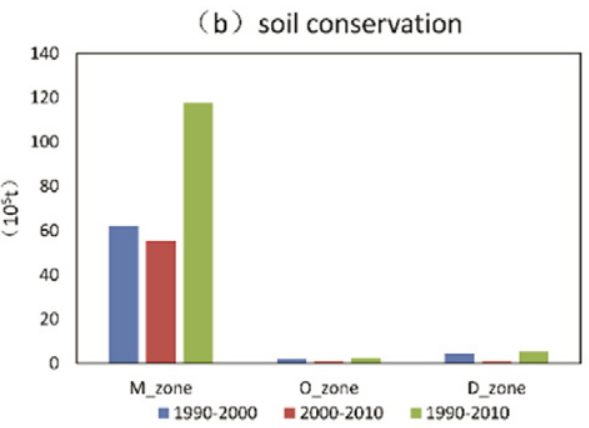

(d) sand fixation

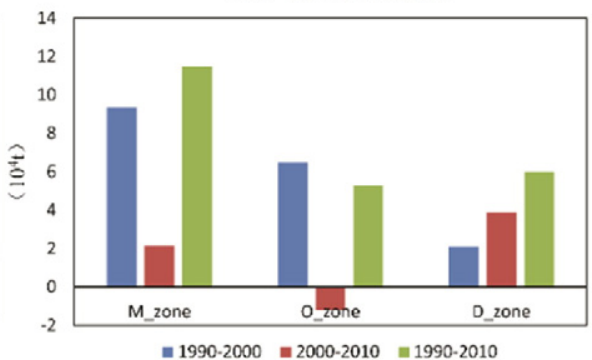

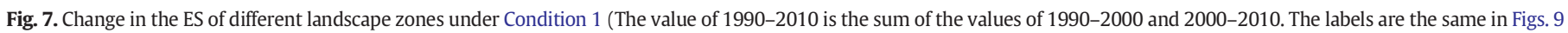
and 11). 

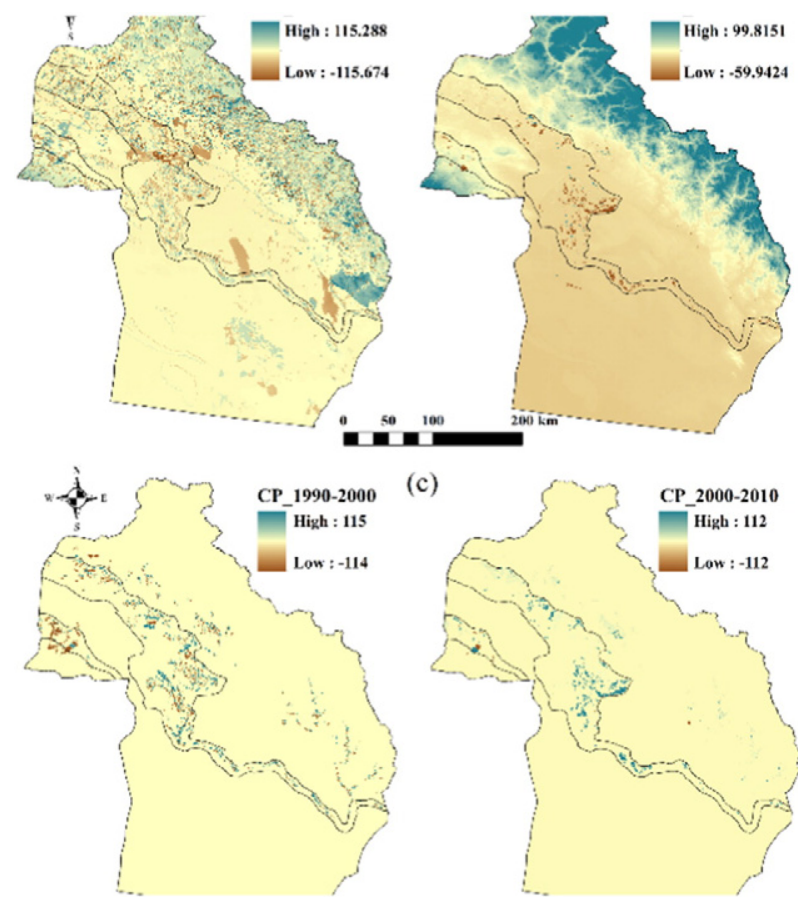

(c)

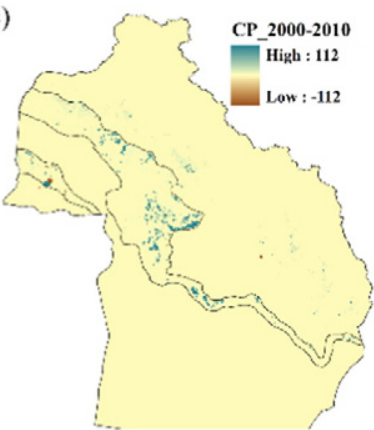

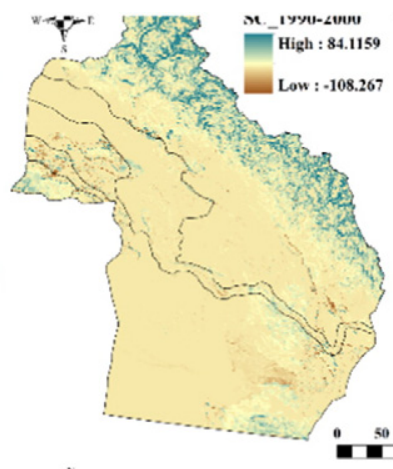

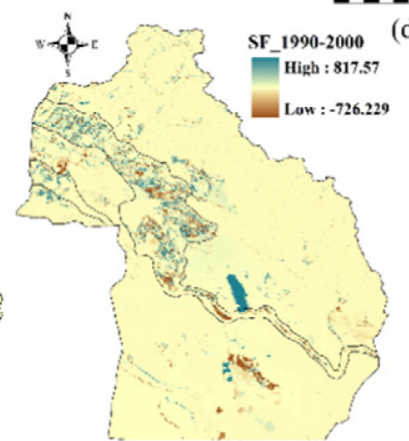

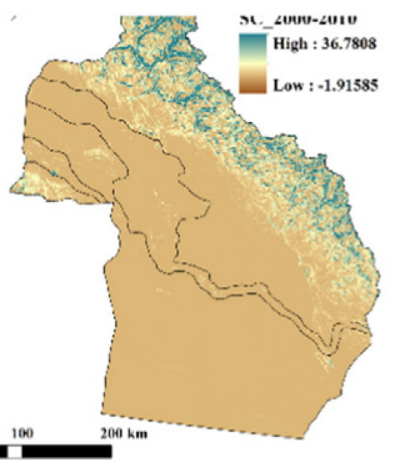

(d)

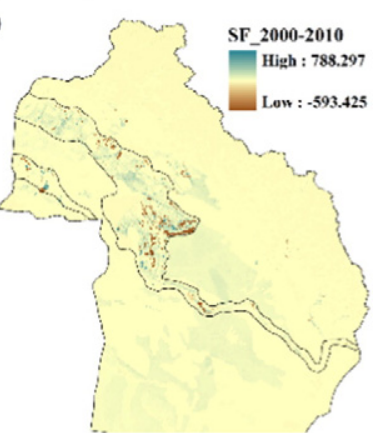

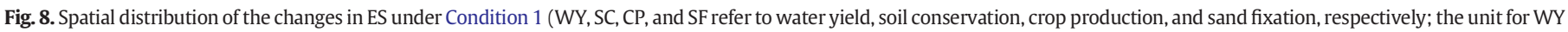
is $\mathrm{mm}$, and the unit for $\mathrm{SC}, \mathrm{CP}$, and SF is $\mathrm{t} / \mathrm{km}^{2}$. These units are the same in Figs. 10 and 12).

increased from $2.28 \times 10^{5}$ t to $2.98 \times 10^{5}$ t, a $29.41 \%$ increase. Fig. $7 \mathrm{c}$ shows that crop production first decreased and then slightly increased in the mountain zone and that a substantial increase in the oasis zone occurred between 2000 and 2010 . The area of decreased production was mainly distributed in the western part of the study area and the area of increased production was mainly distributed in the middle of the oasis zone (Fig. 8c). (4) Sand Fixation. The amount of sand fixation showed an overall increasing trend from $4.61 \times 10^{6} \mathrm{t}$ in 1990 to $4.84 \times 10^{6} \mathrm{t}$ in 2010 , an increase of $4.99 \%$. In the first ten years, sand fixation in the mountain zone, oasis zone, and desert zone all increased, but in the last ten years, sand fixation declined in the oasis zone (Fig. 7d). The areas of decline were mainly distributed at the edges of the oasis and desert zones, which were the sources of wind erosion (Fig. 8d).

\subsubsection{Condition 2: land use change only}

In Condition 2, which examined the influence of land use change only, the total amounts of the various ES changed little over the past 20 years, but the values varied significantly in the different MODS landscape zones. (1) Water yield. From 1990 to 2010, the water yield increased by $1.15 \times 10^{7} \mathrm{~m}^{3}$ in the mountain zone and by $4.21 \times 10^{7} \mathrm{~m}^{3}$ in the desert zone while it decreased by $1.77 \times 10^{7} \mathrm{~m}^{3}$ in the oasis zone (Fig. 9a). Fig. 10a shows that water yield continually declined in the oasis zone in the last 20 years. (2) Soil conservation. From 1990 to

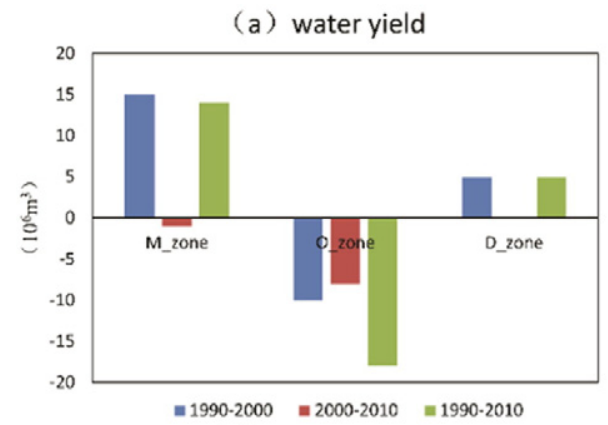

(c) crop production
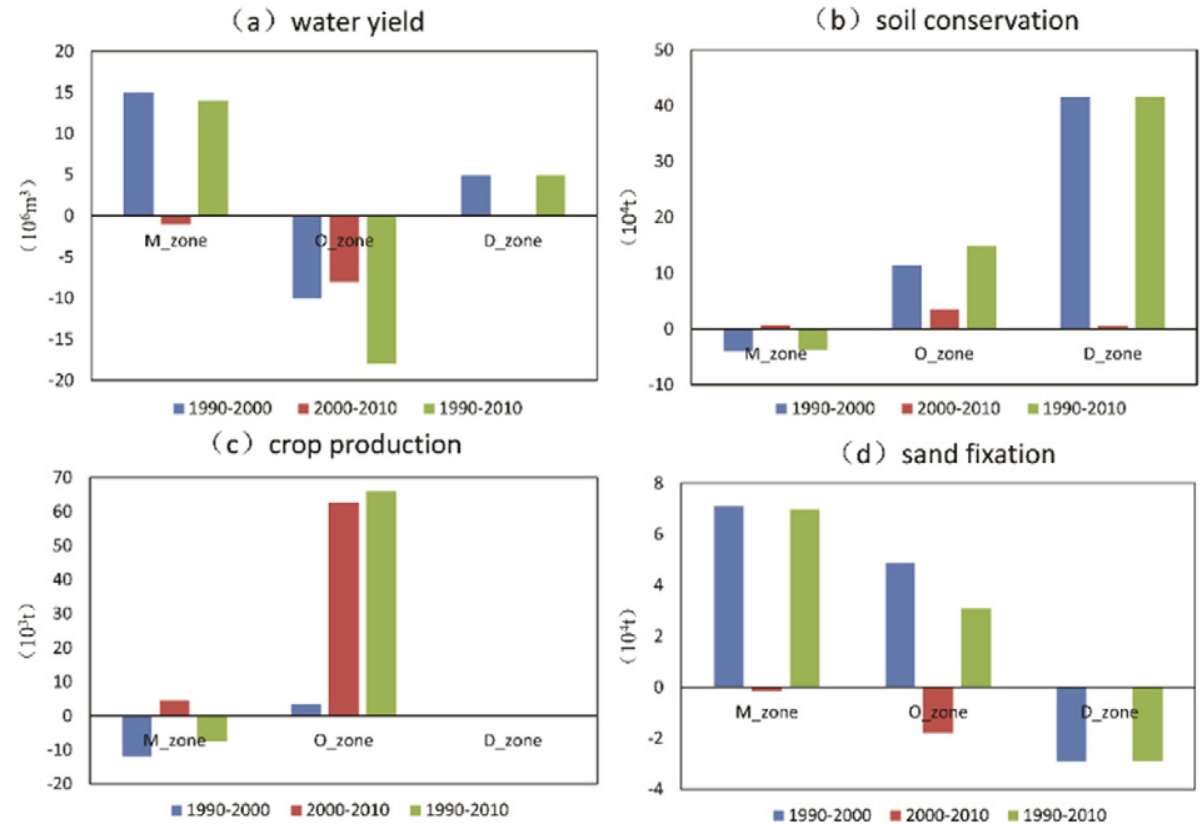

(d) sand fixation

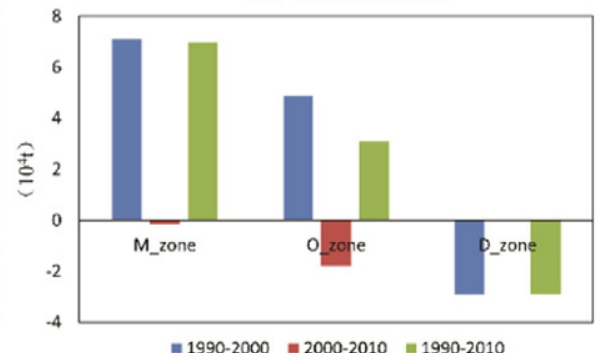

Fig. 9. Change in the ES of different landscape zones under Condition 2. 

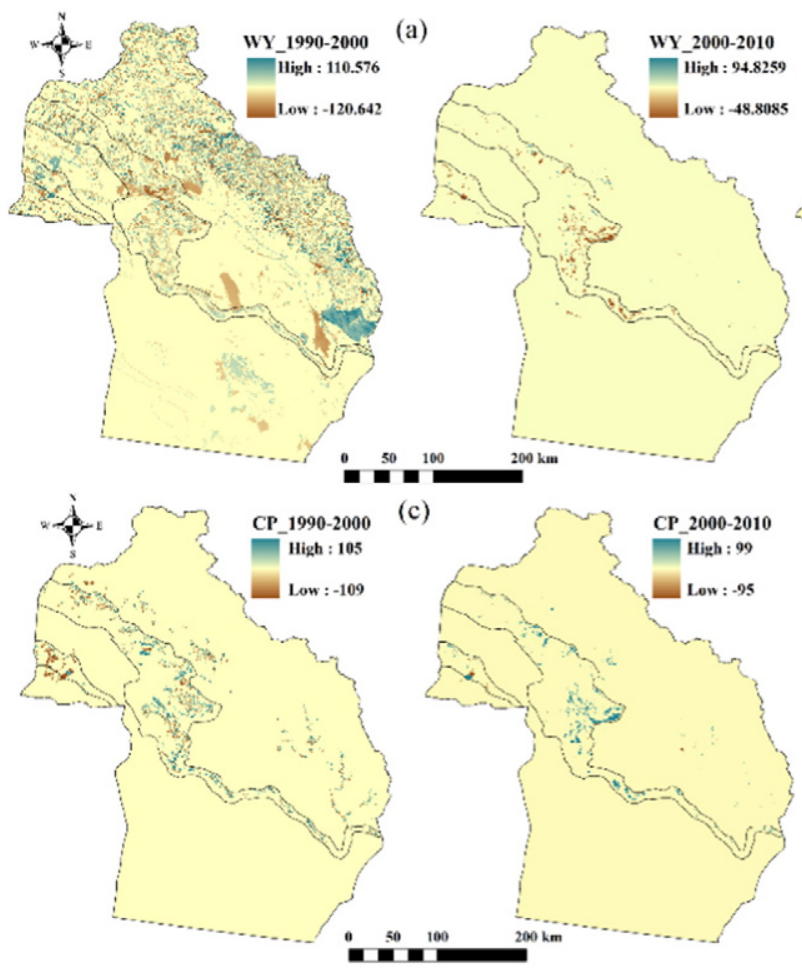
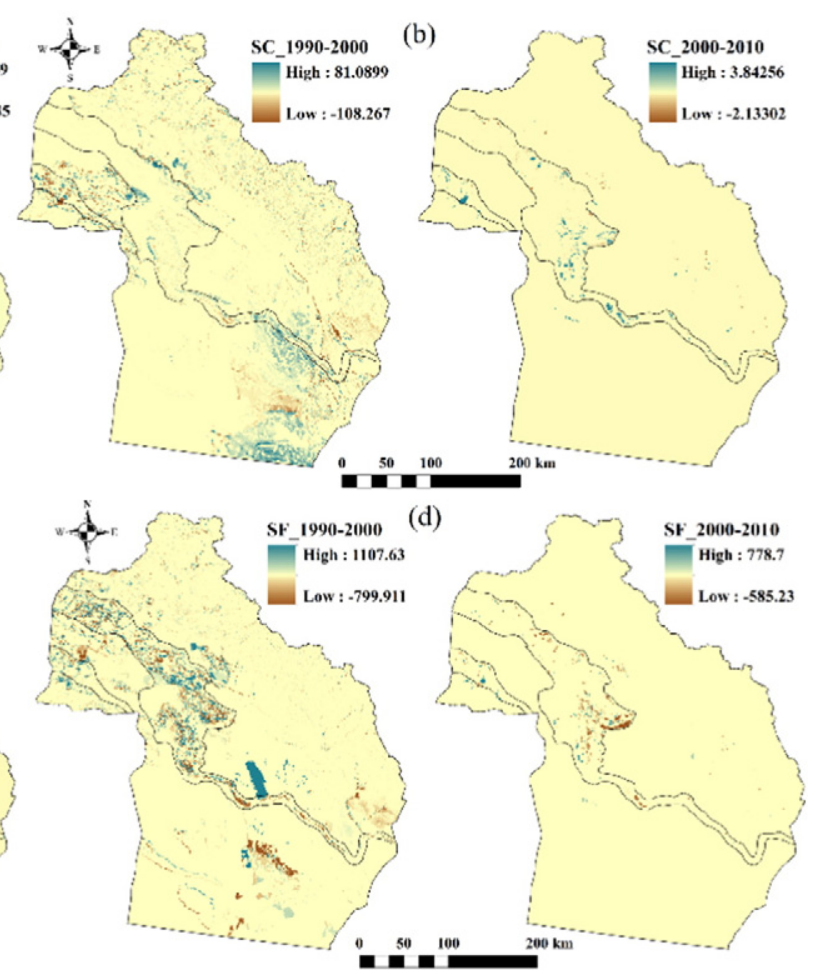

Fig. 10. Spatial distribution of the changes in ES under Condition 2.

2010 , the amount of soil conservation decreased by $1.19 \times 10^{5} \mathrm{t}$ in the mountain zone, but there were increases of $1.49 \times 10^{5} \mathrm{t}$ in the oasis zone and of $4.16 \times 10^{5} \mathrm{t}$ in the desert zone (Fig. 9b). The areas that showed a decline were mainly located in the high-altitude areas of the mountain zone (Fig. 10b). (3) Crop production. Over the past 20 years, crop production decreased by $7.47 \times 10^{3} \mathrm{t}$ in the mountain zone and significantly increased by $6.68 \times 10^{4} \mathrm{t}$ in the oasis zone (Fig. 9c). The areas of decrease were mainly distributed in the western mountain zone and the areas exhibiting an increase were mainly distributed in the central oasis zone (Fig. 10c). (4) Sand fixation. During 1990-2010, the amount of sand fixation increased by $6.99 \times 10^{4} \mathrm{t}$ and $3.10 \times 10^{4} \mathrm{t}$ in the mountain zone and oasis zone, respectively, and decreased by $2.90 \times 10^{4} \mathrm{t}$ in the desert zone (Fig. 9d). The areas exhibiting a decrease were mainly distributed in the ecotones between the oasis zone and the desert zone (Fig. 10d).

\subsubsection{Condition 3: climate change only}

In Condition 3, under the influence of climate change alone, the total amount of ES showed a significant increasing trend. (1) Water yield. From 1990 to 2010 , the water yield increased to $4.01 \times 10^{8} \mathrm{~m}^{3}$, $8.05 \times 10^{7} \mathrm{~m}^{3}$, and $2.38 \times 10^{8} \mathrm{~m}^{3}$, respectively in the mountain, oasis, and desert zones (Fig. 11a). In terms of spatial distribution, the water yield decreased in the oasis zone and in most areas of the desert zone (a) water yield

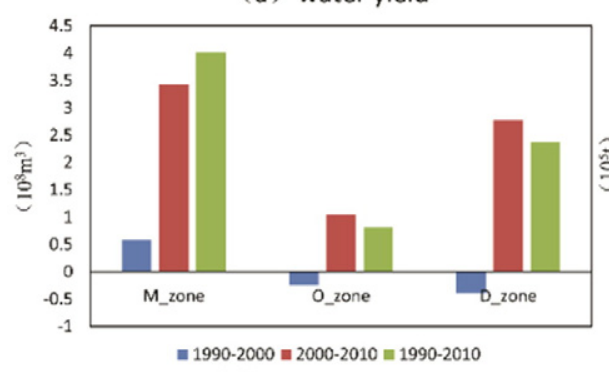

(c) crop production

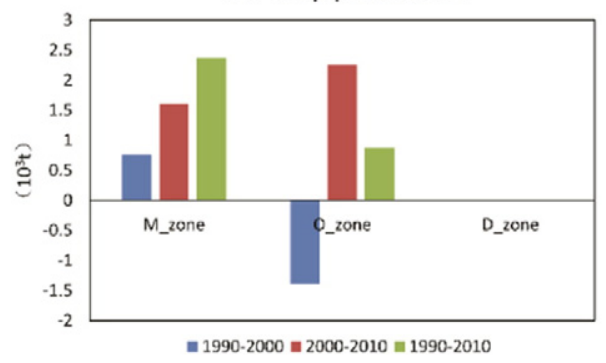

(b) soil conservation

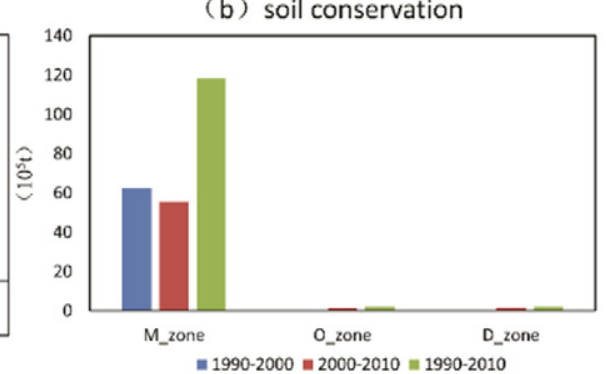

(d) sand fixation

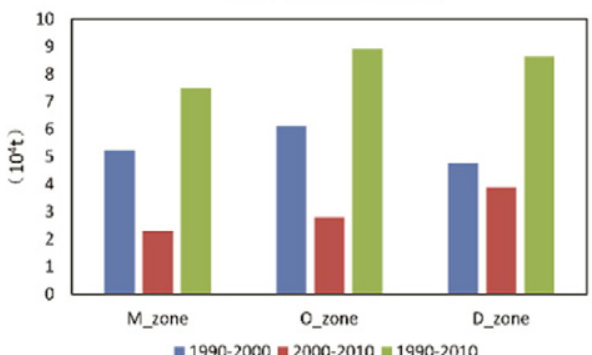

Fig. 11. Changes in the ES of different landscape zones under Condition 3. 

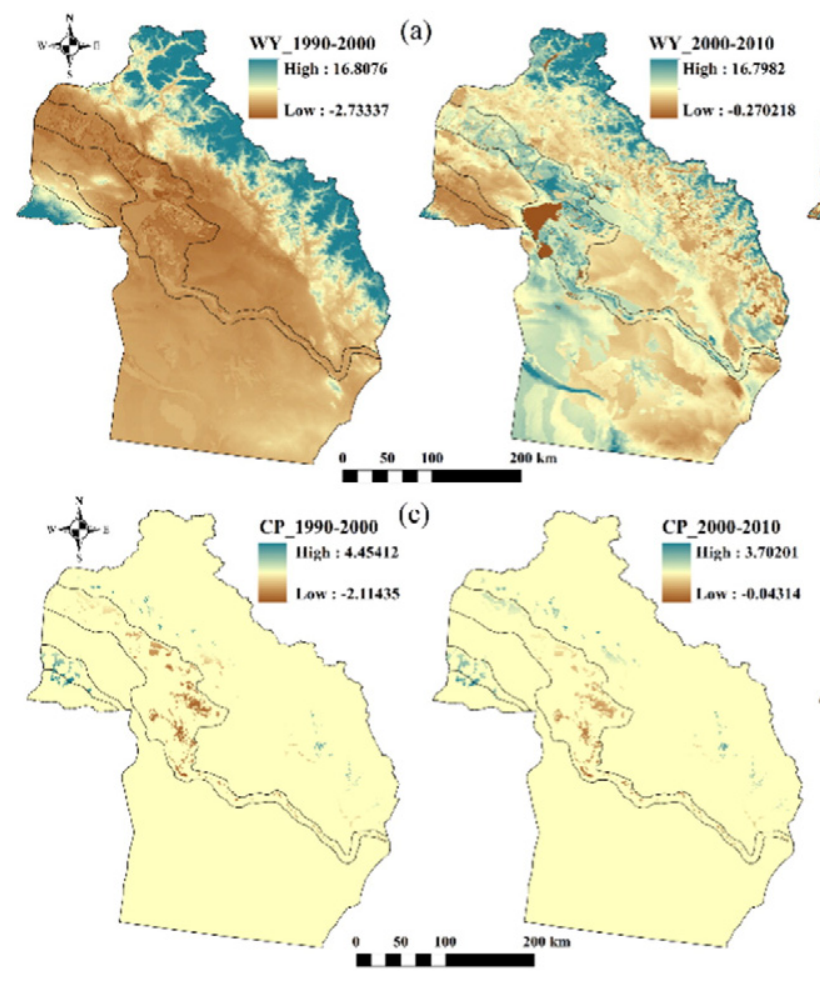

Fig. 12. Spatial distribution of the changes in the ES under Condition 3.

during the first 10 years due to the warming and drying climate (Fig. 12 a). (2) Soil conservation. The amount of soil conservation increased substantially in the mountain zone, while it showed a small increase in the oasis and desert zones (Fig. 11b). The areas of increase were mainly distributed in the high-altitude mountain zone (Fig. 12b). (3) Crop production. Crop production exhibited a continuously increasing trend in the mountain zone, while it declined in the oasis zone by $1.39 \times 10^{3} \mathrm{t}$ from 1990 to 2000 (Fig. 11c). Due to the rising temperature, which exceeded the suitable range for crop growth, crop production decreased in the central oasis zone (Fig. 12c). (4) Sand fixation. The rising temperature affected physical and chemical factors, such as soil moisture, leading to an increase in the potential and actual wind erosion $\left(1.57 \times 10^{7} \mathrm{t}\right.$ and $\left.1.50 \times 10^{7} \mathrm{t}\right)$; therefore, sand fixation tended to increase throughout the entire area over the past 20 years (Fig. 11d). However, it should also be noted that sand fixation significantly decreased in some areas of the desert zone (Fig. 12d).

\section{Discussion}

\subsection{Factors influencing changes in ES}

Land use and climate change are considered the two main driving factors of ES change. Although some studies have explored the effects
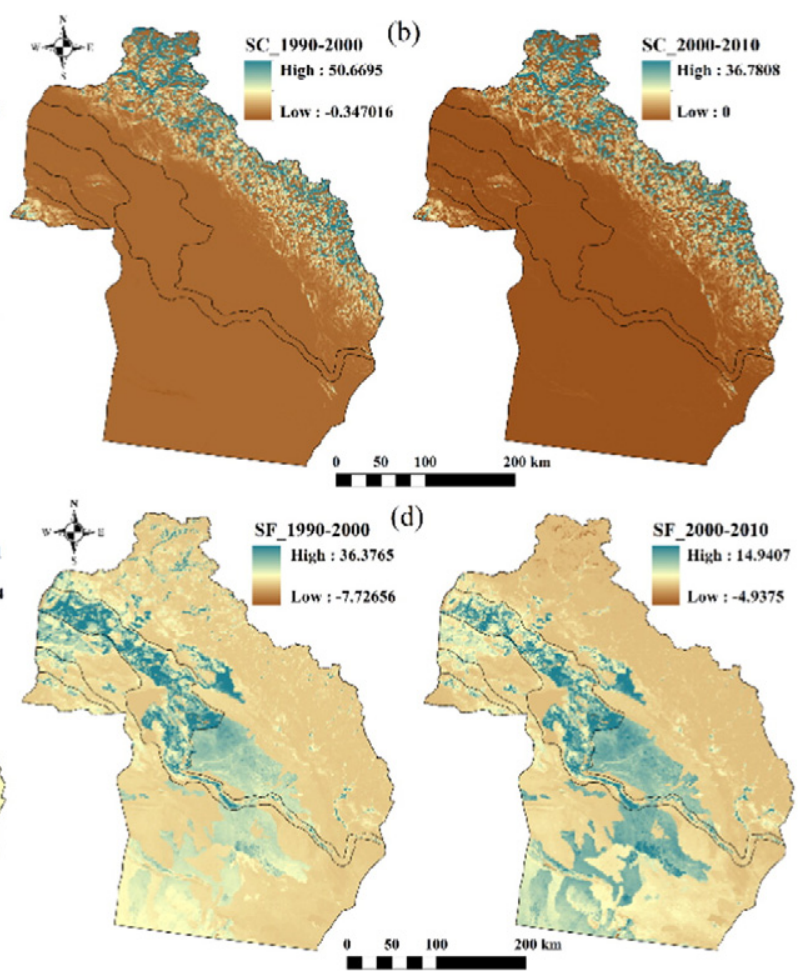

of land use and climate change on ES (Hao et al., 2016; Jiang et al., 2016; Su and Fu, 2013; Wang et al., 2016), they mainly focused on the correlation coefficients between the driving factors and the ES, and the process and location of the impacts were not determined. Therefore, these studies did not offer scientific and targeted guidance for the sustainable use of ES. Based on the MODS concept and various condition settings, we analyzed specific land use conversions and climate change trends resulting in ES changes (Tables 3-6). Moreover, we discussed the significance of these changes with regard to the development of arid regions.

\subsubsection{Land use change}

Over the past 20 years, $19,783 \mathrm{~km}^{2}$ of the study area underwent land use conversion, accounting for $16.86 \%$ of the total area. Generally, ecosystems changed from low vegetation cover to high vegetation cover resulting in increased evapotranspiration and decreased water yield (Gao et al., 2015; Liu et al., 2008; López-Moreno et al., 2011; Wang et al., 2015). Our study found that the conversion of bare land to grassland and to cropland substantially decreased water yield. The area of decline was mainly located in the oasis zone, which was not conducive to agricultural development. Water flow is an important conduit in the MODS biogeochemical cycle. The reduced water yield in the oasis zone will result in soil salinization because not all water and soil salts are

Table 3

The effects of the conversion of the main land use types on ES during 1990-2000.

\begin{tabular}{|c|c|c|c|c|c|}
\hline Land use type conversion & Area $\left(10^{2} \mathrm{~km}^{2}\right)$ & Water yield $\left(10^{5} \mathrm{~m}^{3}\right)$ & Soil conservation $\left(10^{3} \mathrm{t}\right)$ & Crop production $\left(10^{4} \mathrm{t}\right)$ & Sand fixation $\left(10^{4} \mathrm{t}\right)$ \\
\hline Forest to grassland & 45.03 & 150.00 & -69.10 & - & -1.26 \\
\hline Grassland to forest & 34.97 & -5.08 & 58.30 & - & 1.22 \\
\hline Bare land to grassland & 41.67 & -157 & 160.00 & - & 8.14 \\
\hline Grassland to bare land & 30.03 & 80.50 & -76.30 & - & -6.58 \\
\hline Cropland to grassland & 5.72 & 2.26 & 8.20 & -4.94 & 2.92 \\
\hline Grassland to cropland & 5.48 & -2.73 & -6.30 & 4.55 & -2.72 \\
\hline Bare land to grassland & 4.54 & -8.23 & 16.30 & 3.66 & -0.97 \\
\hline Cropland to bare land & 3.84 & 7.13 & -21.30 & -3.27 & 0.44 \\
\hline Forest to cropland & 1.79 & 2.80 & -0.57 & 1.43 & -1.22 \\
\hline Cropland to forest & 1.73 & -2.71 & 2.22 & -1.43 & 0.94 \\
\hline
\end{tabular}


Table 4

The effects of the conversion of the main land use types on ES during 2000-2010.

\begin{tabular}{|c|c|c|c|c|c|}
\hline Land use type conversion & Area $\left(10^{2} \mathrm{~km}^{2}\right)$ & Water yield $\left(10^{5} \mathrm{~m}^{3}\right)$ & Soil conservation $\left(10^{3} \mathrm{t}\right)$ & Crop production $\left(10^{4} \mathrm{t}\right)$ & Sand fixation $\left(10^{4} \mathrm{t}\right)$ \\
\hline Bare land to cropland & 6.32 & -217 & 18.6 & 5.08 & -23.00 \\
\hline Grassland to cropland & 2.39 & -7.23 & -0.12 & 2.02 & -13.90 \\
\hline Bare land to grassland & 0.99 & -8.61 & 2.47 & - & 0.99 \\
\hline Cropland to grassland & 0.62 & 2.79 & 0.56 & -0.55 & 1.15 \\
\hline
\end{tabular}

transported to the desert and thus remain in the cropland (Jobbágy et al., 2011). The conversion of forest to grassland and grassland to bare land led to reduced soil conservation in the mountain zone, with these areas being prone to landslides, mudslides, and other geological hazards (Fu, 2013), which threaten grazing, tourism, etc. This is consistent with similar research by Fu et al. (2011) and Lü et al. (2012) in the Loess Plateau of China. The conversion of grassland to cropland and bare land to cropland resulted in a significant increase in crop production in the oasis zone, especially during 2000-2010. The increase in crop production, which occurred due to the large-scale expansion of cropland, will result in trade-offs with most regulating ES (Kragt and Robertson, 2014; Pan et al., 2013). The conversion of grassland to bare land and bare land to cropland resulted in decreased sand fixation in the desert zone and the oasis-desert ecotones. The reduction of the sand fixation service in the desert zone will severely threaten agricultural development in the oasis zone, as well as human life (Zhao et al., 2008).

Our study also showed that, in addition to the supply of ES, land use change will also affect ES trade-offs and synergies (Fig. 13). Therefore, conversion between different land use types in arid regions must be managed carefully. For example, although water yield and crop production are increased when forest is converted to cropland, soil conservation and sand fixation are reduced. This process will lead to decreased soil fertility, land desertification, and even the inability to grow crops (Akuja et al., 2001). When cropland is converted to grassland, water yield, soil conservation, and sand fixation all show an increasing trend, contrasting with crop production, which is reduced. This indicates that when the crop supply is sufficient, properly returning cropland to grassland is beneficial to the sustainable use of ES (Wang and Bennett, 2008). The conversion of bare land to cropland increases soil conservation and crop production while weakening water yield and sand fixation. Once the water supply and the protection of vegetation against sand become insufficient, agricultural development will become unsustainable. Therefore, the study of the correlation between land use change and ES trade-offs should be strengthened in the future (Bennett et al., 2009; Jia et al., 2014).

\subsubsection{Climate change}

Precipitation and temperature play important roles in various ecological processes (Runting et al., 2016). Both precipitation and temperature increased gradually during 1990-2010 in Altay Prefecture, with the changes exhibiting spatial heterogeneity (Fig. 6). During 1990-2000, approximately $1 / 3$ of the total area showed a warming and drying trend, which resulted in a decrease in water yield, soil conservation, and crop production and an increase in sand fixation. In contrast, approximately $2 / 3$ of the total area showed a warming and wetting trend, and all types of ES increased. Sand fixation increased mainly due to the potential wind erosion, and the actual wind erosion also increased. In fact, the wind erosion should be classified as an ecosystem disservice (EDS) (Vaz et al., 2017). During 2000-2010, a cooling and wetting trend occurred in $1 / 6$ of the total area; water yield, soil conservation, and crop production increased, and sand fixation decreased. Approximately 5/6 of the total area showed a warming and wetting trend, and all ES exhibited an increasing trend.

Our study found that the warming and drying climate led to the decline of ES and the increase of EDS, which increased pressures on the agricultural development of the oasis zone and the ecological conservation of the desert zone. The warming and drying climate resulted in less precipitation in the oasis zone. Water resources are the most important factors affecting crop growth in arid regions; an inadequate water supply leads directly to reduced crop production (Huang et al., 2012). At the same time, desiccation increased the possibility of desertification, increasing the threat to the ecological security of the oasis zone. Moreover, with the intensification of climate warming, areas with permanent glacial snow cover in the mountain zone decreased by 8.33\% from 1990 to 2010. Rising temperatures lead to rainfall rather than snowfall, and melting glaciers cannot be restored (Petersen and Pellicciotti, 2011). Therefore, effective management measures must be taken to mitigate the impact of climate change in the future (Nelson et al., 2013).

\subsection{Strategies for sustainable use of ES in the MODS}

The MODS has unique natural and economic characteristics, and planning for future resource use must be linked with environmental protection (Wu and Zhang, 2000). The mountain zone, oasis zone, and desert zone are integrated systems linked by the flow of energy, materials, and values (Zhang, 2001). Therefore, strategies for the sustainable use of ES should be designed from a global perspective.

(1) Mountain zone. Forests and grasslands play an important role in controlling erosion and have the ability to store water, thus ensuring that the oasis zone is sufficiently protected and supplied with materials (Fu et al., 2015). We recommend that the local government prohibit overgrazing while simultaneously planting grasslands with high coverage in the oasis zone to convert large-scale mountain grazing to grazing in the oasis zone, which will enhance the livelihoods of herdsmen and reduce environmental damage. (2) Oasis zone. Agriculture is the basis for economic development in arid regions, and it must be continuously strengthened. However, the oasis zone is a very fragile ecosystem, and blindly reclaiming cropland will increase the harm caused by sand erosion and secondary soil salinization. For that reason, development of these areas via the large-scale expansion of cropland should be abandoned in the future and investment in science and technology should be increased to improve agricultural development. In particular, water use efficiency must be improved to adapt to reduced future precipitation due to climate change (Hong and Yabe, 2016). In addition, soil fertility is limited in arid regions, but crop and pasture rotation can effectively restore soil fertility. Therefore, we advocate planting grasslands with high coverage in the oasis zone. (3) Desert zone. Vegetation coverage in the desert zone is low and large-scale grazing will destroy the soil crust, increasing the risk of desertification (Manzano and

Table 5

ES changes under different trends of climate change during 1990-2000.

\begin{tabular}{|c|c|c|c|c|c|}
\hline Climate change & Area $\left(10^{4} \mathrm{~km}^{2}\right)$ & Water yield $\left(10^{7} \mathrm{~m}^{3}\right)$ & Soil conservation $\left(10^{3} \mathrm{t}\right)$ & Crop production $\left(\times 10^{3} \mathrm{t}\right)$ & Sand fixation $\left(\times 10^{4} \mathrm{t}\right)$ \\
\hline Warming and drying & 4.11 & -5.13 & -7.30 & -1.95 & 8.55 \\
\hline Warming and wetting & 7.63 & 4.59 & 6300.00 & 1.34 & 7.54 \\
\hline
\end{tabular}


Návar, 2000). Shrubs have a strong ability to provide windbreaks and promote sand fixation, but shrub clearing will lead to the direct exposure of the oasis zone to wind erosion. Therefore, measures such as establishing nature reserve and replanting shrubs in the poorly protected areas should be implemented.

The MODS is widespread in Central Asia, and it is more common in Xinjiang, China (Sun et al., 2007). Researchers have conducted several relevant studies on ES in Central Asia (Dong et al., 2012; Kolinjivadi et al., 2016; Mislimshoeva et al., 2016), but there have been few comprehensive studies linking the MODS and ES. Our study reveals ways in which land use and climate change influence the spatial and temporal variations of ES in Altay Prefecture. Moreover, we put forward some targeted suggestions for the sustainable use of ES. The methodology and suggestions can provide valuable reference information for regions with a similar MODS structure.

\subsection{Uncertainties in model-based ES assessment}

Generally, there are uncertainties associated with the assessment of ES (Hou et al., 2013). In this study, the InVEST model does not differentiate between surface runoff, underground runoff, and soil runoff, so the interactions between surface water and ground water were neglected entirely when assessing the water yield (Sharp et al., 2016; Su and Fu, 2013). Because there have been few studies of the $C$ and $P$ factors in the arid regions of China, we referred to the results of previous studies when assessing soil conservation, an approach which introduced some inaccuracies (Jiang et al., 2016). When crop production was assessed using the SAORES model, the crop varieties were not categorized and the results only reflected the potential crop production capacity ( $\mathrm{Hu}$ et al., 2015). For sand fixation, the RWEQ model simplified the complexity of wind erosion, and the nonlinear space approach combined with GIS technology and modeling likely led to uncertainties in the results (Guo et al., 2012). In addition, all data used in this study had a resolution of $1 \mathrm{~km} \times 1 \mathrm{~km}$, resulting in a loss of detail for some minor land use types and slope fluctuations, which was another source of uncertainty. However, it is more important to understand the overall spatial distribution pattern of ES and the trends in variation in large-scale ES studies. With improvements in the resolution of land use, soil, and other data and the further calibration of model parameters in future research, the uncertainties in ES research will be gradually reduced.

\section{Conclusion}

This study assessed four ES based on widely used biophysical models and analyzed the effects of different land use and climate change conditions on ES. The results showed that the total amount of each ES increased during the period of 1990-2010 under the influence of land use and climate change, but there was a significant decline in some areas in terms of the spatial distribution. The impact of land use change on ES indicated that in the past 20 years, the area of forest and bare land decreased sharply, the area of cultivated land increased greatly, and the area of grassland with high coverage and middle coverage decreased severely. These effects resulted in reduced soil conservation in the mountain zone, reduced water yield in the oasis zone, and reduced sand fixation in the desert zone. Thus, land use change has increased the risk of soil salinization in the oasis zone and reduced the protection the oasis zone receives from the mountain zone and desert zone. The spatial differences in climate change, especially the warming and drying trend, led to decreased water yield in the oasis zone and increased wind

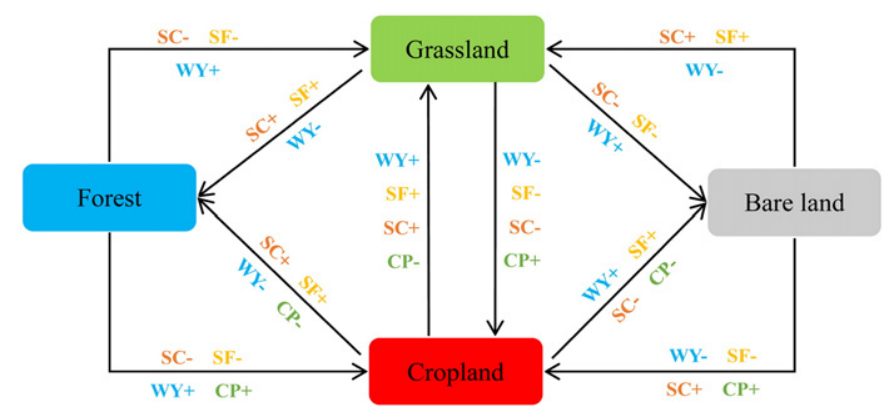

Fig. 13. The effects of the conversion of the main land use types on the relationships among ES (WY, SC, CP, and SF refer to water yield, soil conservation, crop production, and sand fixation, respectively; '+' indicates enhancement of the ES under conversion; '-' indicates a reduction).

erosion in the desert zone. These resulted in less water storage in the oasis zone, thus greatly inhibiting agricultural development. At the same time, desiccation increased the likelihood of desertification, which is the greatest threat to the ecological security of the oasis zone.

We provide a methodology to quantify the influences of land use and climate change on ES and identify the location of the influences. Based on the results, we recommend that local governments achieve sustainable use of ES by planting grasslands with high coverage in the oasis zone, increasing investment in agricultural science and technology, and establishing protected areas in the mountain and desert zones. The alternating distribution of alpine-basin terrestrial ecosystems is widespread in the arid regions of Central Asia. Therefore, the methodology used here can also be applied to other regions with a MODS structure.

\section{Acknowledgments}

This work was supported by the National Science and Technology Support Plan of China (No. 2014BAC15B04). We extend our thanks to the China Meteorological Data Sharing Service System, Environmental and Ecological Science Data Centre for West China, Xinjiang and Central Asia Data Center, and National Earth System Science Data Sharing Infrastructure for their support in this study. We would like to thank the anonymous reviewers for their valuable comments and suggestions.

\section{References}

Akuja, T., Avni, Y., Zaady, E., Gutterman, Y., 2001. Soil erosion effects as indicators of desertification processes in the northern Negev Desert. Soil Eros. Res. 21st Century, Proc., pp. 595-598

Bateman, I.J., Harwood, A.R., Mace, G.M., Watson, R.T., Abson, D.J., Andrews, B., Binner, A., Crowe, A., Day, B.H., Dugdale, S., Fezzi, C., Foden, J., Hadley, D., Haines-Young, R. Hulme, M., Kontoleon, A., Lovett, A. a, Munday, P., Pascual, U., Paterson, J., Perino, G., Sen, A., Siriwardena, G., van Soest, D., Termansen, M., 2013. Bringing ecosystem services into economic decision-making: land use in the United Kingdom. Science 341:45-50. http://dx.doi.org/10.1126/science.1234379.

Bennett, E.M., Peterson, G.D., Levitt, E.A., 2005. Looking to the future of ecosystem services. Ecosystems 8:125-132. http://dx.doi.org/10.1007/s10021-004-0078-y.

Bennett, E.M., Peterson, G.D., Gordon, L.J., 2009. Understanding relationships among multiple ecosystem services. Ecol. Lett. 12:1394-1404. http://dx.doi.org/10.1111/j.1461 0248.2009.01387.x.

Burkhard, B., Kandziora, M., Hou, Y., Müller, F., 2014. Ecosystem service potentials, flows and demands-concepts for spatial localisation, indication and quantification. Landscape 34:1-32. http://dx.doi.org/10.3097/LO.201434 (Online).

Cai, C., Ding, S., Shi, Z., Huang, L., Zhang, G., 2000. Study of applying USLE and geographical information system IDRISI to predict soil erosion in small watershed. J. Soil Water Conserv. 14, 19-24.

Table 6

ES changes under different trends of climate change during 2000-2010.

\begin{tabular}{|c|c|c|c|c|c|}
\hline Climate change & Area $\left(10^{4} \mathrm{~km}^{2}\right)$ & Water yield $\left(10^{8} \mathrm{~m}^{3}\right)$ & Soil conservation $\left(10^{6} \mathrm{t}\right)$ & Crop production $\left(\times 10^{3} \mathrm{t}\right)$ & Sand fixation $\left(\times 10^{3} \mathrm{t}\right)$ \\
\hline Cooling and wetting & 1.81 & 1.23 & 3.29 & 0.22 & -1.08 \\
\hline Warming and wetting & 9.93 & 6.02 & 2.35 & 3.66 & 88.70 \\
\hline
\end{tabular}


Canadell, J., Jackson, R., Ehleringer, J., Mooney, H.A., Sala, O.E., Schulze, E.-D., 1996. Maximum rooting depth of vegetation types at the global scale. Oecologia 108:583-595. http://dx.doi.org/10.1007/BF00329030.

Chen, L., Xie, G., Zhang, C., Liu, C., Chen, C., Wang, H., 2013. Ecosystem function and regionalization in the Lancang river basin. Resour. Sci. 35, 816-823.

Chuai, X., Huang, X., Wu, C., Li, J., Lu, Q., Qi, X., Zhang, M., Zuo, T., Lu, J., 2016. Land use and ecosystems services value changes and ecological land management in coastal Jiangsu, China. Habitat Int. 57:164-174. http://dx.doi.org/10.1016/j.habitatint.2016.07.004.

Costanza, R., D'Arge, R., De Groot, R.S., Farber, S., Grasso, M., Hannon, B., Limburg, K. Naeem, S., O'Neill, R.V., Paruelo, J., Raskin, R.G., Sutton, P., van den Belt, M., 1997. The value of the world's ecosystem services and natural capital. Nature http://dx. doi.org/10.1038/387253a0.

Daily, G.C., 1997. Nature's Services: Societal Dependence On Natural Ecosystems (Nature's Serv. Soc. Depend. Nat. Ecosyst.). http://dx.doi.org/10.1017 S1367943098221123.

Dong, X., Zhang, Y., Yan, M., Zhang, X., 2006. Coupling of mountain-basin system and agricultural structure adjustment in north of Tianshan mountain. Res. Agric. Mod. 27 377-379.

Dong, X., Yang, W., Ulgiati, S., Yan, M., Zhang, X., 2012. The impact of human activities on natural capital and ecosystem services of natural pastures in North Xinjiang China. Ecol. Model. 225:28-39. http://dx.doi.org/10.1016/j.ecolmodel.2011.11.006.

Estoque, R.C., Murayama, Y., 2012. Examining the potential impact of land use/cover changes on the ecosystem services of Baguio city, the Philippines: a scenariobased analysis. Appl. Geogr. 35:316-326. http://dx.doi.org/10.1016/j.apgeog. 2012.08.006.

Fryrear, D.W., Saleh, A., Bilbro, J.D., 1998. A single event wind erosion model. Trans. ASAE $41,1369-1374$.

Fu, Q., 2013. The Application of RS and GIS in the Risk Assessment of Calamities of Regional Landslides. Chengdu University of Technology.

Fu, B., Zhang, L., 2014. Land-use change and ecosystem services: concepts, methods and process. Prog. Geogr. 33, 441-446.

Fu, B., Liu, Y., Lü, Y., He, C., Zeng, Y., Wu, B., 2011. Assessing the soil erosion control service of ecosystems change in the Loess Plateau of China. Ecol. Complex. 8:284-293. http:// dx.doi.org/10.1016/j.ecocom.2011.07.003.

Fu, Q., Li, B., Yang, L., Wu, Z., Zhang, X., 2015. Ecosystem services evaluation and its spatial characteristics in Central Asia's arid regions: a case study in Altay Prefecture, China. Sustainability 7:8335-8353. http://dx.doi.org/10.3390/su7078335.

Gao, J., Li, F., Gao, H., Zhou, C., Zhang, X., 2015. The impact of land-use change on waterrelated ecosystem services: a study of the Guishui River Basin, Beijing, China J. Clean. Prod. 1-8. http://dx.doi.org/10.1016/j.jclepro.2016.01.049.

Geng, X., Wang, X., Yan, H., Zhang, Q., Jin, G., 2014. Land use/land cover change induced impacts on water supply service in the upper reach of Heihe River Basin. Sustainability 7:366-383. http://dx.doi.org/10.3390/su7010366.

Gulzat, H., Zhao, J., 2011. Analysis on climate change in recent 50 years in Altay Prefecture,Xinjiang. Arid Zo. Res. 28:268-274. http://dx.doi.org/10.13866/j.azr.2011. 02.023

Guo, Z., 2012. Improvement and Application of RWEQ Model in North China. Beijing Normal University

Guo, Z., Zobeck, T.M., Stout, J.E., Zhang, K., 2012. The effect of wind averaging time on wind erosivity estimation. Earth Surf. Process. Landf. 37:797-802. http://dx.doi.org/ 10.1002/esp.3222.

Hao, R., Yu, D., Liu, Y., Liu, Y., Qiao, J., Wang, X., Du, J., 2016. Impacts of changes in climate and landscape pattern on ecosystem services. Sci. Total Environ. 579:718-728. http:// dx.doi.org/10.1016/j.scitotenv.2016.11.036.

Hong, N.B., Yabe, M., 2016. Improvement in irrigation water use efficiency: a strategy for climate change adaptation and sustainable development of Vietnamese tea production. Environ. Dev. Sustain. 1-17. http://dx.doi.org/10.1007/s10668-0169793-8

Hou, Y., Burkhard, B., Muller, F., 2013. Uncertainties in landscape analysis and ecosystem service assessment. J. Environ. Manag. 127:S117-S131. http://dx.doi.org/10.1016/j. jenvman.2012.12.002

Hou, Y., Li, B., Müller, F., Chen, W., 2016. Ecosystem services of human-dominated watersheds and land use influences: a case study from the Dianchi Lake watershed in China. Environ. Monit. Assess. 188:652. http://dx.doi.org/10.1007/s10661-0165629-0.

Hu, H., Fu, B., Lü, Y., Zheng, Z., 2015. SAORES: a spatially explicit assessment and optimization tool for regional ecosystem services. Landsc. Ecol. 30:547-560. http://dx.doi org/10.1007/s10980-014-0126-8.

Huang, Y., Li, Y.P., Chen, X., Ma, Y.G., 2012. Optimization of the irrigation water resources for agricultural sustainability in Tarim River Basin, China. Agric. Water Manag. 107: 74-85. http://dx.doi.org/10.1016/j.agwat.2012.01.012.

Jia, X., Fu, B., Feng, X., Hou, G., Liu, Y., Wang, X., 2014. The tradeoff and synergy between ecosystem services in the grain-for-green areas in Northern Shaanxi, China. Ecol. Indic. 43:103-111. http://dx.doi.org/10.1016/j.ecolind.2014.02.028.

Jiang, C., Li, D., Wang, D., Zhang, L., 2016. Quantification and assessment of changes in ecosystem service in the Three-river Headwaters Region, China as a result of climate variability and land cover change. Ecol. Indic. 66:199-211. http://dx.doi.org/10.1016/j. ecolind.2016.01.051.

Jing, W., Feng, M., Yang, Y., 2013. A statistical downscaling approach of NCEP/NCAR reanalysis temperature data. Int. J. Geogr. Inf. Sci. 15, 819-828.

Jobbágy, E.G., Nosetto, M.D., Villagra, P.E., Jackson, R.B., 2011. Water subsidies from mountains to deserts: their role in sustaining groundwater-fed oases in a sandy landscape. Ecol. Appl. 21:678-694. http://dx.doi.org/10.1890/09-1427.1.

Kolinjivadi, V., Charré, S., Adamowski, J., Kosoy, N., 2016. Economic experiments for collective action in the Kyrgyz Republic : lessons for payments for ecosystem services (PES) economic experiments for collective action in the Kyrgyz Republic : lessons for payments for ecosystem services (PES). Ecol. Econ. http://dx.doi.org/10.1016/j. ecolecon.2016.06.029 (in press).

Kragt, M.E., Robertson, M.J., 2014. Quantifying ecosystem services trade-offs from agricultural practices. Ecol. Econ. 102:147-157. http://dx.doi.org/10.1016/j.ecolecon.2014. 04.001 .
Kremen, C., 2005. Managing ecosystem services: what do we need to know about their ecology? Ecol. Lett. 8:468-479, http://dx.doi.org/10.1111/j.1461-0248.2005.00751.x.

Le Maitre, D.C., Milton, S.J., Jarmain, C., Colvin, C.A., Saayman, I., Vlok, J.H.J., 2007. Linking ecosystem services and water resources: landscape-scale hydrology of the Little Karoo. Front. Ecol. Environ. http://dx.doi.org/10.1890/1540-9295(2007)5[261: LESAWR]2.0.CO;2.

Li, Y., Luo, Y., Liu, G., Ouyang, Z., Zheng, H., 2013. Effects of land use change on ecosystem services: a case study in Miyun reservoir watershed. Acta Ecol. Sin. 33:726-736. http://dx.doi.org/10.5846/stxb201205280787.

Liu, B.Y., Nearing, M.A., Risse, L.M., 1994. Slope gradient effects on soil loss for steep slopes. Trans. ASAE 37:1835-1840. http://dx.doi.org/10.13031/2013.28273.

Liu, B.Y., Nearing, M.A., Shi, P.J., Jia, Z.W., 2000. Slope length effects on soil loss for steep slopes. Soil Sci. Soc. Am. J. 64:1759-1763. http://dx.doi.org/10.2136/sssaj2000. 6451759x.

Liu, M., Tian, H., Chen, G., Ren, W., Zhang, C., Liu, J., 2008. Effects of land-use and landcover change on evapotranspiration and water yield in China during 1900-2000. J. Am. Water Resour. Assoc. 44:1193-1207. http://dx.doi.org/10.1111/j.1752-1688. 2008.00243.x

López-Moreno, J.I., Vicente-Serrano, S.M., Moran-Tejeda, E., Zabalza, J., Lorenzo-Lacruz, J., García-Ruiz, J.M., 2011. Impact of climate evolution and land use changes on water yield in the ebro basin. Hydrol. Earth Syst. Sci. 15:311-322. http://dx.doi.org/10. 5194/hess-15-311-2011.

Lorencová, E., Frélichová, J., Nelson, E., Vačkář, D., 2013. Past and future impacts of land use and climate change on agricultural ecosystem services in the Czech Republic. Land Use Policy 33:183-194. http://dx.doi.org/10.1016/j.landusepol.2012.12.012.

Lü, Y., Fu, B., Feng, X., Zeng, Y., Liu, Y., Chang, R., Sun, G., Wu, B., 2012. A policy-driven large scale ecological restoration: quantifying ecosystem services changes in the loess plateau of China. PLoS One 7:1-10. http://dx.doi.org/10.1371/journal.pone.0031782.

Manzano, M.G., Návar, J., 2000. Processes of desertification by goats overgrazing in the Tamaulipan thornscrub (matorral) in north-eastern Mexico. J. Arid Environ. 44: 1-17. http://dx.doi.org/10.1006/jare.1999.0577.

McCool, D.K., Brown, L.C., Foster, G.R., Mutchler, C.K., Meyer, L.D., 1987. Revised slope steepness factor for the universal soil loss equation. Trans. Am. Soc. Agric. Eng. 30: 1387-1396. http://dx.doi.org/10.13031/2013.30576.

Mendoza-González, G., Martínez, M.L., Lithgow, D., Pérez-Maqueo, O., Simonin, P., 2012. Land use change and its effects on the value of ecosystem services along the coast of the Gulf of Mexico. Ecol. Econ. 82:23-32. http://dx.doi.org/10.1016/j.ecolecon. 2012.07.018

Millennium Ecosystem Assessment, 2005. Ecosystems and Human Well-being: Wetlands and Water Synthesis. The Millennium Ecosystem Assessment Series; Ecosystems and Human Well-being vol. 1. http://dx.doi.org/10.1007/BF02987493.

Mislimshoeva, B., Herbst, P., Koellner, T., 2016. Current pathways towards good forest governance for ecosystem services in the former Soviet republic Tajikistan. Forest Policy Econ. 63:11-19. http://dx.doi.org/10.1016/j.forpol.2015.12.002.

Nelson, E., Sander, H., Hawthorne, P., Conte, M., Ennaanay, D., Wolny, S., Manson, S., Polasky, S., 2010. Projecting global land-use change and its effect on ecosystem service provision and biodiversity with simple models. PLoS One 5. http://dx.doi.org/ 10.1371/journal.pone.0014327.

Nelson, E.J., Kareiva, P., Ruckelshaus, M., Arkema, K., Geller, G., Girvetz, E., Goodrich, D., Matzek, V., Pinsky, M., Reid, W., Saunders, M., Semmens, D., Tallis, H., 2013. Climate change's impact on key ecosystem services and the human well-being they support in the US. Front. Ecol. Environ. 11:483-493. http://dx.doi.org/10.1890/120312.

Nemani, R.R., Keeling, C.D., Hashimoto, H., Jolly, W.M., Piper, S.C., Tucker, C.J., Myneni, R.B., Running, S.W., 2003. Climate-driven increases in global terrestrial net primary production from 1982 to 1999. Science 300:1560-1563. http://dx.doi.org/10.1126/ science. 1082750 .

Pan, Y., Xu, Z., Wu, J., 2013. Spatial differences of the supply of multiple ecosystem services and the environmental and land use factors affecting them. Ecosyst. Serv. 5: 4-10. http://dx.doi.org/10.1016/j.ecoser.2013.06.002

Perrings, C, Naeem, S., Ahrestani, F., Bunker, D.E, Burkill, P., Canziani, G, Elmqvist, T. Ferrati, R., Fuhrman, J., Jaksic, F., Kawabata, Z., Kinzig, a., Mace, G.M., Milano, F., Mooney, H., Prieur-Richard, a.-H., Tschirhart, J., Weisser, W., 2010. Ecosystem Services for 2020. Science 330 (80):323-324. http://dx.doi.org/10.1126/science. 1196431

Petersen, L., Pellicciotti, F., 2011. Spatial and temporal variability of air temperature on a melting glacier: atmospheric controls, extrapolation methods and their effect on melt modeling, Juncal Norte Glacier, Chile. J. Geophys. Res. Atmos. 116. http://dx. doi.org/10.1029/2011JD015842.

Polasky, S., Nelson, E., Pennington, D., Johnson, K.A., 2011. The impact of land-use change on ecosystem services, biodiversity and returns to landowners: a case study in the state of Minnesota. Environ. Resour. Econ. 48:219-242. http://dx.doi.org/10.1007/ s10640-010-9407-0.

Runting, R.K., Bryan, B.A., Dee, L.E., Maseyk, F.J.F., Mandle, L., Hamel, P., Wilson, K.A., Yetka, K, Possingham, H.P. Rhodes, J R, 2016. Incorporating climate change into ecosystem service assessments and decisions: a review. Glob. Chang. Biol. 28-41. http://dx.doi. org/10.1111/gcb.13457.

Schröter, D., Cramer, W., Leemans, R., Prentice, I.C., Araújo, M.B., Arnell, N.W., Bondeau, A., Bugmann, H., Carter, T.R., Gracia, C.A., de la Vega-Leinert, A.C., Erhard, M., Ewert, F., Glendining, M., House, J.I., Kankaanpää, S., Klein, R.J.T., Lavorel, S., Lindner, M., Metzger, M.J., Meyer, J., Mitchell, T.D., Reginster, I., Rounsevell, M., Sabaté, S., Sitch, S., Smith, B., Smith, J., Smith, P., Sykes, M.T., Thonicke, K., Thuiller, W., Tuck, G., Zaehle, S., Zierl, B., 2005. Ecosystem service supply and vulnerability to global change in Europe. Science 310:1333-1337. http://dx.doi.org/10.1126/science.1115233.

Sharp, R., Tallis, H.T., Ricketts, T., Guerry, A.D., Wood, S.A., Chaplin-Kramer, R., Nelson, E., Ennaanay, D., Wolny, S., Olwero, N., Vigerstol, K., Pennington, D., Mendoza, G., Aukema, J., Foster, J., Forrest, J., Cameron, D., Arkema, K., Lonsdorf, E.K., Kennedy, C., Verutes, G., Kim, C.K., Guannel, G., Papenfus, M., Toft, J., Marsik, M., Bernhardt, J., Griffin, R. Glowinski, K. Chaumont, N. Perelman, A., Lacayo, M., Mandle, L., Hamel, P., Vogl, A.L., Rogers, L., Bierbower, W., 2016. InVEST User Guide. The Natural Capital Project, Stanford University, University of Minnesota, The Nature Conservancy, and World Wildlife Fund http://dx.doi.org/10.1007/s13398-014-0173-7.2. 
Sharpley, A.N., Williams, J.R., 1990. EPIC-erosion/productivity impact calculator: 1. Model documentation. Tech. Bull. 4. United States Dep. Agric, pp. 206-207.

$\mathrm{Su}, \mathrm{C}$., Fu, B., 2013. Evolution of ecosystem services in the Chinese Loess Plateau under climatic and land use changes. Glob. Planet. Chang. 101:119-128. http://dx.doi.org/10. 1016/j.gloplacha.2012.12.014.

Sun, H., Wang, R., Yang, G., 2007. The mountain-oasis-desert system and characteristics of climate in the arid zone of Center Asia. J. Arid L. Resour. Environ. 21:6-11. http://dx. doi.org/10.13448/j.cnki.jalre.2007.10.002.

Tallis, H., Polasky, S., 2009. Mapping and valuing ecosystem services as an approach for conservation and natural-resource management. Ann. N. Y. Acad. Sci. 1162: 265-283. http://dx.doi.org/10.1111/j.1749-6632.2009.04152.x.

Van Pelt, R.S., Zobeck, T.M., Potter, K.N., Stout, J.E., Popham, T.W., 2004. Validation of the wind erosion stochastic simulator (WESS) and the revised wind erosion equation (RWEQ) for single events. Environmental Modelling and Software:pp. 191-198 http://dx.doi.org/10.1016/S1364-8152(03)00122-1.

Vaz, A.S., Kueffer, C., Kull, C.A., Richardson, D.M., Vicente, J.R., Kühn, I., Schröter, M., Hauck, J., Bonn, A., Honrado, J.P., 2017. Integrating ecosystem services and disservices: insights from plant invasions. Ecosyst. Serv. 23:94-107. http://dx.doi.org/10.1016/j. ecoser.2016.11.017.

Vitousek, P.M., Mooney, H. a, Lubchenco, J., Melillo, J.M., 1997. Human domination of earth's ecosystems. Science 277 (80):494-499. http://dx.doi.org/10.1126/science. 277.5325.494.

Wang, X., Bennett, J., 2008. Policy analysis of the conversion of cropland to forest and grassland program in China. Environ. Econ. Policy Stud. 9:119-143. http://dx.doi. org/10.1007/BF03353986.

Wang, W., Guo, H., Chuai, X., Dai, C., Lai, L., Zhang, M., 2014. The impact of land use change on the temporospatial variations of ecosystems services value in China and an optimized land use solution. Environ. Sci. Pol. 44:62-72. http://dx.doi.org/10.1016/j. envsci.2014.07.004.

Wang, Z., Mao, D., Li, L., Jia, M., Dong, Z., Miao, Z., Ren, C., Song, C., 2015. Quantifying changes in multiple ecosystem services during 1992-2012 in the Sanjiang Plain of China. Sci. Total Environ. 514:119-130. http://dx.doi.org/10.1016/j.scitotenv.2015. 01.007.

Wang, H., Zhou, S., Li, X., Liu, H., Chi, D., Xu, K., 2016. The influence of climate change and human activities on ecosystem service value. Ecol. Eng. 87:224-239. http://dx.doi. org/10.1016/j.ecoleng.2015.11.027.
Wischmeier, W.H., Smith, D.D., 1965. Predicting Rainfall Erosion Losses From Crop Land East of the Rocky Mountains. USDA-ARS, Washington, DC.

Wu, G., Zhang, Y., 2000. Study on regional system of oasis in China. J. Arid L. Resour. Environ. $14,1-10$.

Wu, J., Li, B., Zhang, X., Xia, Y., Chong, J., 2007. Land use/cover change and ecosystem service values in the north Tianshan Mountains. Arid L. Geogr. 30, 728-735.

Zhang, X., 2001. Ecological restoration and sustainable agricultural paradigm of Mountain-Oasis-Ecotone-Desert system in the north of the Tianshan mountains. J. Integr. Plant Biol. 43, 1294-1299.

Zhang, F., 2011. The coupled ecology effect and the function position for oasis-mountaindesert system in arid land: a case of Manas river valley. J. Arid L. Resour. Environ. 25 52-56.

Zhang, L., Dawes, W.R., Walker, G.R., 2001. Response of mean annual evapotranspiration to vegetation changes at catchment scale. Water Resour. Res. 37:701-708. http:// dx.doi.org/10.1029/2000WR900325

Zhang, K., Peng, W., Yang, H., 2007. Soil erodibility and its estimation for agricultural soil in China. Acta Pedol. Sin. 44, 7-13.

Zhang, Y., Song, C., Zhang, K., Cheng, X., Band, L.E., Zhang, Q., 2014. Effects of land use/land cover and climate changes on terrestrial net primary productivity in the Yangtze River basin, China, from 2001 to 2010. J. Geophys. Res. Biogeosci. 119:1092-1109. http://dx.doi.org/10.1002/2014JG002616.

Zhao, W., Hu, G., Zhang, Z., He, Z., 2008. Shielding effect of oasis-protection systems composed of various forms of wind break on sand fixation in an arid region: a case study in the Hexi Corridor, northwest China. Ecol. Eng. 33:119-125. http://dx.doi.org/10. 1016/j.ecoleng.2008.02.010.

Zheng, Z., Fu, B., Hu, H., Sun, G., 2014. A method to identify the variable ecosystem services relationship across time: a case study on Yanhe Basin, China. Landsc. Ecol. 29 1689-1696. http://dx.doi.org/10.1007/s10980-014-0088-x.

Zhou, G., Zhang, X., 1996. Study on NPP of natural vegetation in China under global climate change. Acta Phytoecol. Sin. 20, 11-19.

Zhou, W.Z., Liu, G.H., Pan, J.J., Feng, X.F., 2005. Distribution of available soil water capacity in China. J. Geogr. Sci. 15:3-12. http://dx.doi.org/10.1360/gs050101. 